\title{
Trends of ozone total columns and vertical distribution from FTIR observations at eight NDACC stations around the globe
}

\author{
C. Vigouroux ${ }^{1}$, T. Blumenstock ${ }^{2}$, M. Coffey ${ }^{3}$, Q. Errera $^{1}$, O. García ${ }^{4}$, N. B. Jones ${ }^{5}$, J. W. Hannigan ${ }^{3}$, F. Hase ${ }^{2}$, \\ B. Liley ${ }^{6}$, E. Mahieu ${ }^{7}$, J. Mellqvist ${ }^{8}$, J. Notholt ${ }^{9}$, M. Palm ${ }^{9}$, G. Persson ${ }^{8}$, M. Schneider ${ }^{4}$, C. Servais ${ }^{7}$, D. Smale ${ }^{6}$, \\ L. Thölix ${ }^{10}$, and M. De Mazière ${ }^{1}$ \\ ${ }^{1}$ Department of Atmospheric Composition, Belgian Institute for Space Aeronomy (BIRA-IASB), Brussels, Belgium \\ ${ }^{2}$ Karlsruhe Institute of Technology (KIT), Institute for Meteorology and Climate Research (IMK-ASF), Karlsruhe, Germany \\ ${ }^{3}$ Atmospheric Chemistry Division, National Center for Atmospheric Research (NCAR), Boulder, Colorado, USA \\ ${ }^{4}$ Izaña Atmospheric Research Centre (IARC), Agencia Estatal de Meteorología (AEMET), Santa Cruz de Tenerife, Spain \\ ${ }^{5}$ Centre for Atmospheric Chemistry, University of Wollongong, Wollongong, Australia \\ ${ }^{6}$ Department of Atmosphere, National Institute of Water and Atmospheric Research Ltd (NIWA), Lauder, New Zealand \\ ${ }^{7}$ Institute of Astrophysics and Geophysics, University of Liège (ULg), Liège, Belgium \\ ${ }^{8}$ Department of Earth and Space Science, Chalmers University of Technology, Göteborg, Sweden \\ ${ }^{9}$ Institute of Environmental Physics, University of Bremen, Bremen, Germany \\ ${ }^{10}$ Climate Research, Finnish Meteorological Institute (FMI), Helsinki, Finland \\ Correspondence to: C. Vigouroux (corinne.vigouroux@ aeronomie.be)
}

Received: 11 July 2014 - Published in Atmos. Chem. Phys. Discuss.: 25 September 2014

Revised: 19 February 2015 - Accepted: 23 February 2015 - Published: 16 March 2015

\begin{abstract}
Ground-based Fourier transform infrared (FTIR) measurements of solar absorption spectra can provide ozone total columns with a precision of $2 \%$ but also independent partial column amounts in about four vertical layers, one in the troposphere and three in the stratosphere up to about $45 \mathrm{~km}$, with a precision of $5-6 \%$. We use eight of the Network for the Detection of Atmospheric Composition Change (NDACC) stations having a long-term time series of FTIR ozone measurements to study the total and vertical ozone trends and variability, namely, Ny-Ålesund $\left(79^{\circ} \mathrm{N}\right)$, Thule $\left(77^{\circ} \mathrm{N}\right)$, Kiruna $\left(68^{\circ} \mathrm{N}\right)$, Harestua $\left(60^{\circ} \mathrm{N}\right)$, Jungfraujoch $\left(47^{\circ} \mathrm{N}\right)$, Izaña $\left(28^{\circ} \mathrm{N}\right)$, Wollongong $\left(34^{\circ} \mathrm{S}\right)$ and Lauder $\left(45^{\circ} \mathrm{S}\right)$. The length of the FTIR time series varies by station but is typically from about 1995 to present. We applied to the monthly means of the ozone total and four partial columns a stepwise multiple regression model including the following proxies: solar cycle, quasi-biennial oscillation (QBO), El Niño-Southern Oscillation (ENSO), Arctic and Antarctic Oscillation (AO/AAO), tropopause pressure (TP), equivalent latitude (EL), Eliassen-Palm flux (EPF), and volume of polar stratospheric clouds (VPSC).
\end{abstract}

At the Arctic stations, the trends are found mostly negative in the troposphere and lower stratosphere, very mixed in the middle stratosphere, positive in the upper stratosphere due to a large increase in the 1995-2003 period, and non-significant when considering the total columns. The trends for midlatitude and subtropical stations are all non-significant, except at Lauder in the troposphere and upper stratosphere and at Wollongong for the total columns and the lower and middle stratospheric columns where they are found positive. At Jungfraujoch, the upper stratospheric trend is close to significance $\left(+0.9 \pm 1.0 \% \mathrm{decade}^{-1}\right)$. Therefore, some signs of the onset of ozone mid-latitude recovery are observed only in the Southern Hemisphere, while a few more years seem to be needed to observe it at the northern mid-latitude station.

\section{Introduction}

While the past negative trend in the ozone layer has been successfully attributed to the increase of ozone depleting substances and reproduced by chemistry-climate models, under- 
standing and predicting the current and future ozone layer, and especially attributing an ozone recovery to the positive effect of the Montreal Protocol and its Amendments and Adjustments, is still a challenge. This results from natural variability, observation uncertainties, and changes in dynamics and temperature induced by the increase of greenhouse gases (WMO, 2010). Long-term measurements of total and vertical ozone are required to understand the ozone response to different natural and anthropogenic forcings. Since the long-term satellite experiments ceased to operate (i.e., SAGE, HALOE), the satellite community is working on merging the past records to the new measurements performed by a number of satellite instruments launched since 2000 (e.g., Bodeker et al., 2013; Kyrölä et al., 2013; Sioris et al., 2014; Chehade et al., 2014). Reliable data from stable instruments are needed to validate these satellite-extended data sets, and to offer an alternative determination of ozone total and vertical changes. Ground-based (Dobson, Umkehr) and ozonesonde data are traditionally used for these studies, already reporting trends in the 1985 ozone report (WMO, 1985) and followed in 1998 by lidar and microwave measurements (WMO, 1998). Ground-based FTIR (Fourier transform infrared) measurements derived from high-resolution solar absorption spectra provide an additional ozone data set; they were first used for trend studies in Vigouroux et al. (2008) with 10 years of data (1995-2004) at several European stations and then were updated in the WMO (2010) report. Additional similar studies have been performed at individual stations (Mikuteit, 2008; García et al., 2012). These measurements have their own advantages. First, for atmospheric gases such as ozone, which have very narrow absorption lines, the ozone absorption signatures are self-calibrated with the reference being the surrounding continuum. Therefore, the derived absolute ozone columns depend mainly on the employed spectroscopic parameters which dominate the systematic uncertainty budget. Second, they can provide not only ozone total columns with a precision of $2 \%$, but also low vertical resolution profiles, obtained from the temperature and pressure dependence of the absorption line shapes. This leads to about four independent partial columns, one in the troposphere and three in the stratosphere up to about $45 \mathrm{~km}$, with a precision of about 5-6\%. The instrumental line shape (ILS), which depends on the alignment of the spectrometer, impacts the absorption line shape on which the ozone profile retrievals are based. Hence, it is important to have accurate knowledge of the ILS in order to derive correct ozone profiles and trends.

The work discussed in this paper expands on the previous study of Vigouroux et al. (2008): it is based on longer time series, it includes FTIR data from stations outside of Europe, and it uses a stepwise multiple linear regression model including several explanatory variables for the trend evaluation. It is presented as follows: Sect. 2 provides information about the FTIR ozone observations (retrieval strategies, characterization of the vertical information, time series and seasonality). Section 3 describes the stepwise multiple linear regression model applied to the ozone time series. Section 4 presents and discusses the trend results as well as the explained part of ozone variability. Section 5 summarizes the conclusions.

\section{Ground-based FTIR ozone observations}

\subsection{FTIR monitoring}

Table 1 identifies the ground-based FTIR stations, all part of NDACC (Network for the Detection of Atmospheric Composition Change), that contribute to the present work. The latitudinal coverage is good: from $79^{\circ} \mathrm{N}$ to $45^{\circ} \mathrm{S}$. These stations perform regular solar absorption measurements, under clear-sky conditions and over a wide spectral range (around $600-4500 \mathrm{~cm}^{-1}$ ); the derived time series of total column abundances of many atmospheric species are available in the NDACC database (http://www.ndacc.org). While the stations are all currently active, they started their regular monitoring activities at different times. The period of measurement used for ozone trend analysis at each station is summarized in Table 1, together with the instrument manufacturer and type. Some of the stations performed measurements even earlier but these older spectra, taken with different spectrometers, have to be carefully reanalyzed first before being included in a trend study. The instruments currently used are the high-resolution spectrometers Bruker $120 \mathrm{M}, 125 \mathrm{M}$, $120 \mathrm{HR}$, and $125 \mathrm{HR}$, which can achieve a spectral resolution of $0.0035 \mathrm{~cm}^{-1}$ or better. The Bomem DA8 used in the first years of Wollongong measurements has a spectral resolution of $0.004 \mathrm{~cm}^{-1}$.

\subsection{FTIR retrieval strategy}

We refer to Vigouroux et al. (2008) for more details on the ozone FTIR inversion principles, which are based on the optimal estimation method (Rodgers, 2000). The effort of retrieval homogenization initiated in Vigouroux et al. (2008) has been pursued and we report in Table 2 the common retrieval parameters. The spectroscopic database has been updated to HITRAN 2008 (Rothman et al., 2009). All stations are employing the daily pressure and temperature profiles from NCEP (National Centers for Environmental Prediction). A common source for the ozone a priori profiles is used: the model WACCM4 (Whole Atmosphere Community Climate Mode; Garcia et al., 2007) calculated at each FTIR station, except at Harestua where a climatology based on ozonesondes and HALOE measurements is used. Finally, the interfering species fitted in the ozone retrievals, usually with a simple scaling of their a priori profile, are the same for all stations, except Harestua, namely, $\mathrm{H}_{2} \mathrm{O}, \mathrm{CO}_{2}, \mathrm{C}_{2} \mathrm{H}_{4}$, and the ozone isotopologues ${ }^{668} \mathrm{O}_{3}$ and ${ }^{686} \mathrm{O}_{3}$. At Harestua, only $\mathrm{H}_{2} \mathrm{O}$ and $\mathrm{CO}_{2}$ are fitted. 
Table 1. Characteristics of the FTIR stations that contribute to the present work: location and altitude (in kma.s.1.), time period covered by the ozone measurements used in the present trend analysis, and instrument type.

\begin{tabular}{lrrrll}
\hline Station & Latitude & Longitude & Altitude $(\mathrm{km})$ & Time period & Instrument \\
\hline Ny-Ålesund & $79^{\circ} \mathrm{N}$ & $12^{\circ} \mathrm{E}$ & 0.02 & $1995-2012$ & Bruker 120 HR \\
Thule & $77^{\circ} \mathrm{N}$ & $69^{\circ} \mathrm{W}$ & 0.22 & $1999-2012$ & Bruker 120 M \\
Kiruna & $68^{\circ} \mathrm{N}$ & $20^{\circ} \mathrm{E}$ & 0.42 & $1996-2007$ & Bruker 120 HR \\
& & & & $2007-2012$ & Bruker 125 HR \\
Harestua & $60^{\circ} \mathrm{N}$ & $11^{\circ} \mathrm{E}$ & 0.60 & $1995-2009$ & Bruker 120 M \\
& & & & $2009-2012$ & Bruker 125 M \\
Jungfraujoch & $47^{\circ} \mathrm{N}$ & $8^{\circ} \mathrm{E}$ & 3.58 & $1995-2012$ & Bruker 120 HR \\
Izaña & $28^{\circ} \mathrm{N}$ & $16^{\circ} \mathrm{W}$ & 2.37 & $1999-2005$ & Bruker 120 M \\
& & & & $2005-2012$ & Bruker 125 HR \\
Wollongong & $34^{\circ} \mathrm{S}$ & $151^{\circ} \mathrm{E}$ & 0.03 & $1996-2007$ & Bomem DA8 \\
& & & & $2007-2012$ & Bruker 125 HR \\
Lauder & $45^{\circ} \mathrm{S}$ & $170^{\circ} \mathrm{E}$ & 0.37 & $2001-2012$ & Bruker 120 HR \\
\hline
\end{tabular}

Some retrieval parameters still differ from station to station, either for historical reasons or for the inherent specificities of the different locations. They are also summarized in Table 2.

First, two different profile retrieval algorithms are widely used depending on each team's expertise: PROFFIT9 (Hase, 2000) at Kiruna and Izaña and SFIT2 (Pougatchev et al., $1995)$ at the six other stations. It has been demonstrated in Hase et al. (2004) that the profiles and total column amounts retrieved from these two different algorithms under identical conditions are in excellent agreement.

Second, the microwindow sets involve some common lines at all stations, which ensures that only a small bias is expected due to the different microwindow choices. Either some additional thin microwindows are used together with the $1000-1005 \mathrm{~cm}^{-1}$ or, at Kiruna and Izaña, a different choice was led by the priority given to avoid the more intense $\mathrm{H}_{2} \mathrm{O}$ lines while still having a high DOFS (degrees of freedom for signal). All choices of microwindows lead to the required 4-5 DOFS, thanks to the numerous ozone lines with different intensities which give information both in the stratosphere and the troposphere. The test has been made at Kiruna and Ny-Ålesund to use the $1000-1005 \mathrm{~cm}^{-1}$ window only and, as expected, only little impact has been observed: except for Ny-Ålesund's tropospheric trends (1.4\%/decade), we obtained small trend differences of between 0.0 and $0.8 \%$ decade $^{-1}$, which is in all cases well below the uncertainty on the trends (see Section 4). However, it is planned, within the InfraRed Working Group of NDACC, to fix a common choice of microwindows for future improved homogenization.

Third, the main interfering species in this spectral region is water vapor, and it has been dealt with differently depending on the station: at the Wollongong and Lauder stations, the $\mathrm{H}_{2} \mathrm{O}$ profile is retrieved simultaneously with the ozone profile, adding the microwindow of $896.4-896.6 \mathrm{~cm}^{-1}$ for a better $\mathrm{H}_{2} \mathrm{O}$ determination. At Kiruna, Izaña and Jungfrau- joch, the $\mathrm{H}_{2} \mathrm{O}$ a priori profiles are only scaled in the ozone retrieval but these a priori profiles have been preliminarily retrieved in dedicated $\mathrm{H}_{2} \mathrm{O}$ microwindows for each spectrum (Schneider et al. (2006) for Kiruna and Izaña; Sussmann et al. (2009) for Jungfraujoch). For the very dry Jungfraujoch site, it has been found that preliminary $\mathrm{H}_{2} \mathrm{O}$ retrievals do not improve the quality of the ozone retrievals. At $\mathrm{Ny}-\mathrm{A} l e s u n d$ and Thule, water vapor is treated as the other interfering species: only a scaling of a single a priori profile from WACCM4 is made. Therefore, except at the two latter stations, the $\mathrm{H}_{2} \mathrm{O}$ profile variability has been well taken into account. This may be a future improvement to be done in Ny-Ålesund and Thule strategies. However, the random uncertainties due to the water vapor interference are not dominating the ozone error budget (see Sect. 2.3), and we expect a negligible impact on the ozone trends due to the $\mathrm{H}_{2} \mathrm{O}$ treatment.

Fourth, the choice of the regularization (a priori covariance matrix, $\mathbf{S}_{\mathrm{a}}$, and signal to noise ratio, $\mathrm{SNR}$ ) cannot be easily homogenized because it depends on the real variability of ozone which is different at each station location and on the real SNR achieved by each spectrometer. In optimal estimation, the choice of the a priori covariance matrix $\mathbf{S}_{\mathrm{a}}$ is an important parameter of the inversion process and, together with the measurement noise error covariance matrix $\mathbf{S}_{\epsilon}$, it will lead to the following averaging kernel matrix $\mathbf{A}$ (Rodgers, 2000):

$\mathbf{A}=\left(\mathbf{K}^{T} \mathbf{S}_{\epsilon}^{-1} \mathbf{K}+\mathbf{S}_{\mathrm{a}}^{-1}\right)^{-1} \mathbf{K}^{T} \mathbf{S}_{\epsilon}^{-1} \mathbf{K}$,

where $\mathbf{K}$ is the weighting function matrix that links the measurement vector $\boldsymbol{y}$ to the state vector $\boldsymbol{x}: \boldsymbol{y}=\mathbf{K} \boldsymbol{x}+\boldsymbol{\epsilon}$, with $\epsilon$ representing the measurement error. In our retrievals, we assume $\mathbf{S}_{\epsilon}$ to be diagonal, in which case the diagonal elements are the inverse square of the SNR. The diagonal elements of $\mathbf{S}_{\mathrm{a}}$ represent the assumed variability of the target gas volume mixing ratio (VMR) at a given altitude, and the non-diagonal elements represent the correlation between the VMR at different altitudes. We can see in Table 2 that, ex- 
Table 2. Summary of the ozone retrieval parameters. All microwindow (mw) limits are given in per centimeter units. Ny: Ny-Ålesund; Th: Thule; Ha: Harestua; Ju: Jungfraujoch.

\begin{tabular}{|c|c|c|c|c|}
\hline Parameters & Ny-Ålesund/Thule & Harestua/Jungfraujoch & Kiruna/Izaña & Wollongong/Lauder \\
\hline $\begin{array}{l}\text { Spectroscopic } \\
\text { database }\end{array}$ & HITRAN 2008 & HITRAN 2008 & HITRAN 2008 & HITRAN 2008 \\
\hline $\begin{array}{l}\text { Ozone a priori } \\
\text { profiles }\end{array}$ & WACCM4 & $\begin{array}{l}\text { WACCM4 }(\mathrm{Ju}) \\
\text { climatology based on } \\
\text { sondes and HALOE }(\mathrm{Ha})\end{array}$ & WACCM4 & WACCM4 \\
\hline Retrieval code & SFIT2 $^{\mathrm{a}}$ v3.94 & SFIT2 $^{\mathrm{a}}$ v3.94 & PROFFIT9 $^{b}$ & SFIT2 $^{\mathrm{a}}$ v3.94 \\
\hline Microwindows & $\begin{array}{l}1000-1005 \\
782.56-782.86(\mathrm{Ny}) \\
788.85-789.37(\mathrm{Ny}) \\
993.3-993.8(\mathrm{Ny})\end{array}$ & $1000-1005$ & $\begin{array}{l}991.25-993.80 \\
1001.47-1003.04 \\
1005.0-1006.9 \\
1007.347-1009.003 \\
1011.147-1013.553\end{array}$ & $\begin{array}{l}1000-1005 \\
782.56-782.86 \\
788.85-789.37 \\
993.3-993.8 \\
896.4-896.6\left(\mathrm{H}_{2} \mathrm{O}\right)\end{array}$ \\
\hline
\end{tabular}

\begin{tabular}{|c|c|c|c|c|}
\hline $\begin{array}{l}\mathrm{H}_{2} \mathrm{O} \text { treatment } \\
- \text { a priori profile } \\
\text { - fit in ozone mw }\end{array}$ & $\begin{array}{l}\text { One single profile }(\mathrm{Ny}) \\
\text { Preliminary retrievals in } \\
\text { dedicated } \mathrm{H}_{2} \mathrm{O} \text { mws }(\mathrm{Th}) \\
\text { Scaling retrieval only }\end{array}$ & $\begin{array}{l}\text { One single profile }(\mathrm{Ha}) \\
\text { Preliminary retrievals in } \\
\text { dedicated } \mathrm{H}_{2} \mathrm{O} \text { mws }(\mathrm{Ju}) \\
\text { Scaling retrieval only }\end{array}$ & $\begin{array}{l}\text { Preliminary retrievals } \\
\text { in dedicated } \mathrm{H}_{2} \mathrm{O} \text { mws } \\
\text { Scaling retrieval only }\end{array}$ & $\begin{array}{l}\text { One single profile } \\
\text { Profile retrieval }\end{array}$ \\
\hline $\begin{array}{l}\text { Regularization: } \\
-\mathbf{S}_{\mathrm{a}}\end{array}$ & $\begin{array}{l}\text { Real SNR (depending on } \\
\text { each spectrum), except }{ }^{\mathrm{c}} \\
\text { regions at } \\
1000.85-1001.45 \\
1003.16-1004.5 \\
\text { set to } \mathrm{SNR}=1(\mathrm{Ny}) \\
\text { Constant }=50(\mathrm{Th})\end{array}$ & $\begin{array}{l}\text { Diagonal: } 5-11 \%(\mathrm{Ha}) \\
\text { Diagonal: } 10 \%(\mathrm{Ju}) \\
\text { No interlayer correlation }(\mathrm{Ha}) \\
\text { Interlayer correlation: } \\
\text { Gaussian decay } 4 \mathrm{~km}(\mathrm{Ju}) \\
\text { Constant }=100(\mathrm{Ju}) \\
\text { Constant }=200(\mathrm{Ha})\end{array}$ & $\begin{array}{l}\text { Tikhonov regularization } \\
\text { L1 }\end{array}$ & $\begin{array}{l}\text { Diagonal: } 10 \% \\
\text { Interlayer correlation: } \\
\text { exponential decay } 4 \mathrm{~km} \\
\text { Constant }=150\end{array}$ \\
\hline $\begin{array}{l}\text { Instrumental } \\
\text { Line Shape }\end{array}$ & $\begin{array}{l}\text { Fixed ideal (Ny) } \\
\text { Fixed from LINEFIT } \\
(\mathrm{Th})\end{array}$ & $\begin{array}{l}\text { Fixed from LINEFIT }(\mathrm{Ha}) \\
\text { second-order polynomial fit } \\
\text { of EAP }(\mathrm{Ju})\end{array}$ & $\begin{array}{l}\text { Fixed ideal (Kiruna) } \\
\text { Fixed from LINEFIT } \\
\text { (Izaña) }\end{array}$ & $\begin{array}{l}\text { Fixed ideal } \\
\text { except Bomem spectra: } \\
\text { fourth-order polynomial fit } \\
\text { of EAP }\end{array}$ \\
\hline
\end{tabular}

a Pougatchev et al. (1995);

b Hase (2000);

c in order to mask strong $\mathrm{H}_{2} \mathrm{O}$ absorptions.

cept at Harestua, Kiruna and Izaña, the stations are using an a priori covariance matrix with diagonal elements constant with altitude corresponding to 10,20 or $30 \%$ variability, the largest variability taking place at the high latitude stations Ny-Ålesund and Thule. At Harestua, the diagonal elements of $\mathbf{S}_{\mathrm{a}}$ correspond to $11 \%$ in the stratosphere, de- creasing down to $6 \%$ in the troposphere and to $5 \%$ above $35 \mathrm{~km}$. Except at Ny- $\AA$ lesund, the SNR value is not the real one coming from each individual spectrum but an effective SNR that is used as a regularization parameter. This effective SNR is smaller than the value derived from the inherent noise in the spectra, since the residuals in a spectral fit are 
not only coming from pure measurement noise but also from uncertainties in the model parameters. At Kiruna and Izaña, the regularization is made using the Tikhonov L1 constraint (Tikhonov, 1963). The regularization choice $\left(\mathbf{S}_{\mathrm{a}}\right.$ and $\left.\mathrm{SNR}\right)$ is made at each station in order to obtain stable retrievals with reasonable DOFS. The regularization, via the A matrix, will impact, together with the real natural variability of ozone, the smoothing uncertainty which is the dominant source for the tropospheric and lower stratospheric columns. However, this is mainly a random uncertainty source and it as been shown at Izaña that using Tikhonov regularization or a $\mathbf{S}_{\mathrm{a}}$ matrix obtained from ozone climatological measurements does not impact the ozone trends significantly (García et al., 2012).

The last important parameter is the instrumental line shape (ILS). As already mentioned, the ILS impacts the absorption line shape on which the ozone profile retrievals are based. Hence, if it is not properly included in the forward model or in the retrieval process, and if the alignment of the instrument is changing over time, this could impact the derived ozone trends (García et al., 2012). There are three options for considering the ILS and the choice is led by the type of spectrometer and the availability of cell measurements. A perfect alignment of the instrument would provide an "ideal" ILS: the modulation efficiency amplitude (also called the effective apodization parameter, EAP, at the maximum optical path difference) and the phase error remain equal to 1 and 0 , respectively, along the optical path differences (OPDs). This perfect alignment can usually be achieved and maintained over time by the stable Bruker 120 or $125 \mathrm{HR}$. Even when those spectrometers are used, the alignment must be controlled by $\mathrm{HBr}$ or $\mathrm{N}_{2} \mathrm{O}$ absorption measurements in a lowpressure gas cell and the use of the LINEFIT code, as described in Hase et al. (1999). In this approach, the loss of modulation efficiency and the phase error can be described (1) by 40 parameters (20 for each) at equidistant OPDs, or (2) simply by 2 parameters assuming a linear decline of the modulation efficiency with OPD and a constant phase error. At all stations using the 120 or $125 \mathrm{HR}$ spectrometers, and where the cell measurements were available for the whole period and taken at least twice a year (Ny-Ålesund, Kiruna, Lauder, Wollongong from 2007), the ILS retrieved from LINEFIT was found good and stable: less than $2 \%$ of loss in modulation efficiency at the maximum OPD. It has been therefore considered and fixed as ideal in the forward model. For the stations where the cell measurements were available and where the ILS could not be considered ideal, which was the case for the stations running a Bruker $120 \mathrm{M}$ instrument, the ILS was fixed in the forward model to the parameters obtained by LINEFIT using either option (1) at Thule and Izaña or option (2) at Harestua. At Jungfraujoch up to the early 2000's, and at Wollongong, when the Bomem instrument was used, no cell measurements were performed; hence, it is not possible to use the LINEFIT results in the forward model. To take into account that the ILS may not be ideal, the modulation efficiency is retrieved simultaneously with the ozone profiles by using a polynomial fit of order 2 (Jungfraujoch) or 4 (Wollongong). The phase error has been neglected, i.e., it is treated as ideal. An argument against the use of the ozone absorption line shape to retrieve simultaneously the ozone profiles and the ILS is that a change on the ozone concentration at a given altitude may be interpreted wrongly as a change in the ILS. However, it was found that at Jungfraujoch the fitting of the ILS, instead of assuming that it is ideal, improved the agreement with correlative ozone profiles measurements (Barret et al., 2002), leading to the conclusions that there was enough information in the absorption line shapes to isolate correctly the ILS effect. We conducted the test at Ny-Ålesund to use a polynomial fit (order 2) of the modulation efficiency instead of a fixed ideal ILS. We found very small impact on the trends (less than $0.6 \%$ decade $^{-1}$ for all layers). Of course the situation may differ for stations with worse alignment if this one cannot be reproduced by a polynomial fit of the modulation efficiency. Another solution to deal with periods without cell measurements would be to retrieve independently the ILS using $\mathrm{N}_{2}$ and $\mathrm{CO}_{2}$ lines in the historical solar spectra, since these gases have very well-known vertical profiles, and then fix the ILS to these preliminary derived values in the ozone retrievals.

\subsection{Vertical information in FTIR retrievals}

The vertical information contained in the FTIR retrievals can be characterized by the averaging kernel matrix $\mathbf{A}$ (Eq. 1), as described in detail in Vigouroux et al. (2008). It has been shown in this previous paper that the ozone retrievals provide 4-5 DOFS, depending on the station. Therefore, in addition to total column trends, we provide ozone trends in four independent partial column layers, corresponding to the vertical information. The layer limits have been chosen such that the DOFS is at least 1.0 in each associated partial column. The adopted layers are independent according to the resolution of the averaging kernels, as can be seen in Fig. 1 where the partial column averaging kernels of the four layers in the case of Jungfraujoch and Izaña are shown. Similar averaging kernels are obtained at each station (not shown). Also shown is the sensitivity which is, at each altitude $k$, the sum of the elements of the corresponding averaging kernel $\sum_{i} A_{k i}$ and represents roughly the fraction of the retrieval that comes from the measurement rather than from the a priori information. At Izaña, the sensitivity does not decrease towards 0 at about $50 \mathrm{~km}$ (Fig. 1) because of the use of Tikhonov regularization instead of optimal estimation (García et al., 2012). In the present work, small changes have been made in the partial column limits in comparison to Vigouroux et al. (2008): we avoid the tropopause region at each station, in order to have a better separation between the layer that we call the "tropospheric" layer and the lower stratospheric layer. Due to the high tropopause heights at Izaña $(14.9 \mathrm{~km})$ and Wollongong $(13.8 \mathrm{~km})$, compared to mid- and high-latitude stations (from $10.1 \mathrm{~km}$ at Ny-Ålesund to $11.8 \mathrm{~km}$ at Jungfraujoch), we use 

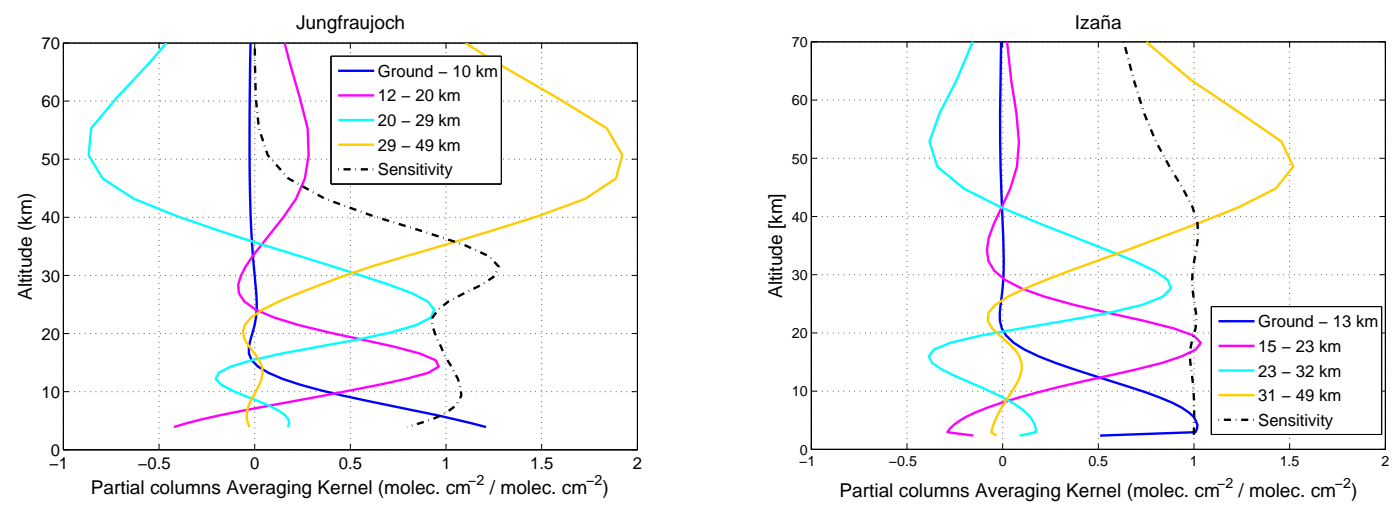

Figure 1. Partial column averaging kernels $\left(\operatorname{molec} \mathrm{cm}^{-2}\left(\operatorname{molec~} \mathrm{cm}^{-2}\right)^{-1}\right)$ for ozone retrievals at Jungfraujoch (left) and Izaña (right) stations.

different partial column limits for these two stations. The upper limit of the upper layer is here $49 \mathrm{~km}$, the altitude above which the DOFS is small (from about 0.01 to 0.04 depending on station), instead of $42 \mathrm{~km}$ in Vigouroux et al. (2008), chosen as the altitude above which the sensitivity was below 0.5 . We still gain from 0.06 (Jungfraujoch) up to 0.23 (Lauder) DOFS in this $7 \mathrm{~km}$ wide range with poorer sensitivity. For Harestua, the chosen layer limits give a DOFS of only 0.9 and 0.75 in the ground $-10 \mathrm{~km}$ and in the $29-49 \mathrm{~km}$ layers, respectively.

We provide in Table 3, for each station, the partial column limits of the four defined layers (Trop: troposphere; LowS: lower stratosphere; MidS: middle stratosphere; UppS: upper stratosphere). The detailed error budget for ozone FTIR retrievals has been described in Vigouroux et al. (2008) and more recently in García et al. (2012) for Izaña; we only just summarize in Table 3 the total random uncertainties obtained for the present choice of layers and for the total columns (TotC). As obtained in the two previous papers, and not shown here, the smoothing error is the dominant random error source for the tropospheric and lower stratospheric layer, while the temperature dominates the random error budget for the middle and upper stratospheric layers and for total columns. Also found in these two papers, and not repeated here, is the validation of the FTIR total and partial columns with correlative data (Dobson, Brewer, UV-Vis, ozonesondes, lidar).

\subsection{FTIR ozone time series}

Figure 2 displays the time series of ozone total columns at each ground-based FTIR station. Because we consider only solar absorption measurements, the time series at $\mathrm{Ny}$ Ålesund, Thule, and Kiruna cover only the mid-MarchSeptember, late-February-mid-October and mid-Januarymid-November periods, respectively. The seasonal variation is isolated in Fig. 3, which shows the monthly mean total columns over the periods of measurements. We clearly see the well-known seasonal cycle of ozone total column having
Table 3. Partial column (PC) limits for the four altitude layers containing at least one DOFS. The random uncertainties are given for each partial column. Trop: troposphere; LowS: lower stratosphere; MidS: middle stratosphere; UppS: upper stratosphere; TotC: total columns; Gd: ground; Err.: total random uncertainties.

\begin{tabular}{llrr}
\hline Layers & Stations & PC limits & Err. \\
\hline \multirow{2}{*}{ Trop } & Izaña/Wollongong & Gd-13/12 km & $6 \%$ \\
& Other stations & Gd-9/10 km & $5 \%$ \\
\hline \multirow{2}{*}{ LowS } & Izaña/Wollongong & $15-23 \mathrm{~km}$ & $5 \%$ \\
& Other stations & $12-20 \mathrm{~km}$ & $4 \%$ \\
\hline \multirow{2}{*}{ MidS } & Izaña/Wollongong & $23-32 \mathrm{~km}$ & $5 \%$ \\
& Other stations & $20-29 \mathrm{~km}$ & $5 \%$ \\
\hline \multirow{2}{*}{ UppS } & Izaña/Wollongong & $31-49 \mathrm{~km}$ & $5 \%$ \\
& Other stations & $29-49 \mathrm{~km}$ & $5 \%$ \\
\hline \multirow{2}{*}{ TotC } & Izaña/Wollongong & - & $2 \%$ \\
& Other stations & - & $2 \%$ \\
\hline
\end{tabular}

a maximum in spring at all stations, and the higher amplitude of the seasonal variation at higher latitudes (Brasseur and Solomon, 1984).

Figure 3 shows also the monthly means of the four partial columns defined in the previous section (Table 3). In the upper stratospheric layer, the ozone maximum occurs in summer (early summer at high latitudes shifting to late summer with decreasing latitude), in agreement with higher photochemical production of ozone during this season. In the lower stratospheric layer, the ozone maximum is in late winter/early spring at all latitudes. The situation is more variable for the middle stratospheric layer: still late winter/early spring for Harestua, Jungfraujoch, Lauder and Wollongong, but the latter shows a second maximum in late summer, and a small amplitude of the seasonal cycle. For the three higher latitude stations - Ny-Ålesund, Thule and Kiruna - the maximum is still in spring, extending to May for the two latter stations. At Izaña, the maximum is in summer in the mid- 

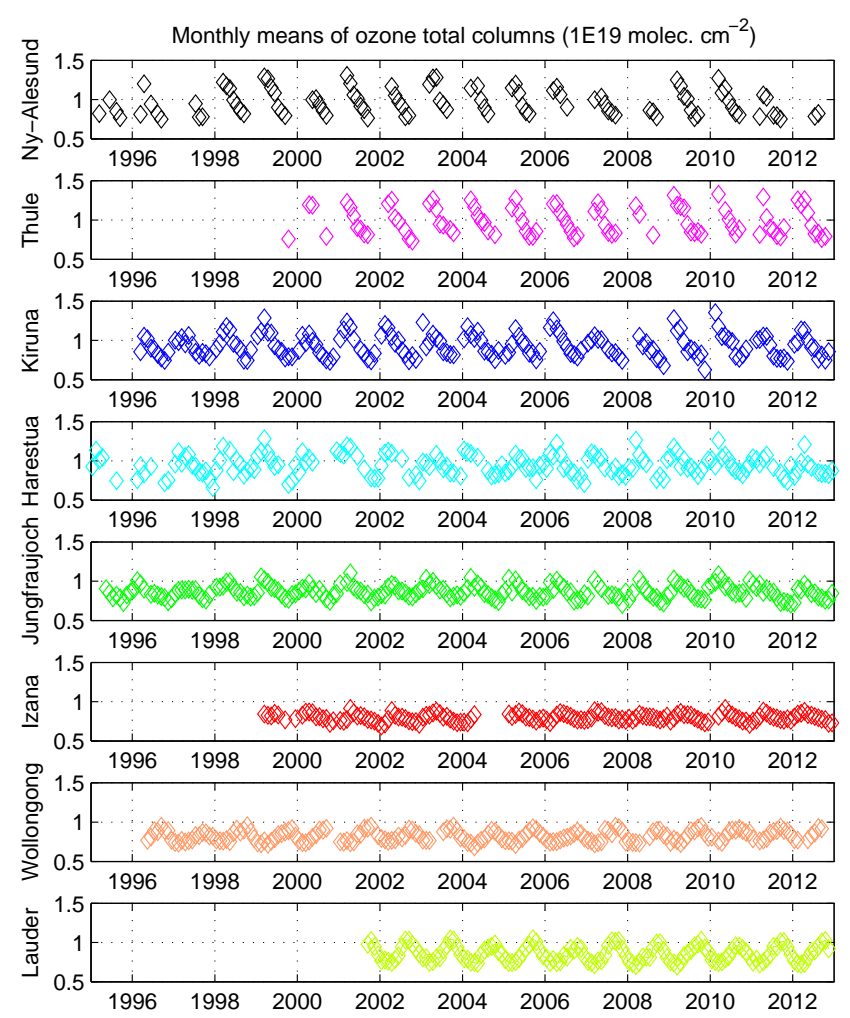

Figure 2. Time series of monthly means of ozone total columns at each station.

dle stratosphere. For the tropospheric column, we observe a maximum in spring at all stations, but at Jungfraujoch it extends also into summer.

\section{Multiple regression model}

The ozone FTIR total and partial column trends in Vigouroux et al. (2008); WMO (2010); García et al. (2012) were calculated with a bootstrap resampling method, applied to the daily means time series. In these studies, only the seasonal cycle and a linear trend were taken into account, the remaining natural ozone variability was then an additional noise in the ozone trend determination. To reduce the uncertainties on the trends and to better understand what drives ozone variability and trends, we use in the present study a multiple linear regression (MLR) model. To reduce the autocorrelation in the residuals, we use here the monthly means time series. Furthermore, to account for the still significant auto-correlation in the residuals, a Cochrane-Orcutt transformation (Cochrane and Orcutt, 1949) is applied to the final model. This gives more reliable confidence intervals for the regression parameters.
The following regression model is applied to the monthly means of ozone total and partial column time series $Y(t)$ :

$$
\begin{aligned}
Y(t) & =A_{0}+A_{1} \cdot \cos (2 \pi t / 12)+A_{2} \cdot \sin (2 \pi t / 12) \\
& +A_{3} \cdot \cos (4 \pi t / 12)+A_{4} \cdot \sin (4 \pi t / 12) \\
& +A_{5} \cdot t+\sum_{k=6}^{n} A_{k} \cdot X_{k}(t)+\epsilon(t),
\end{aligned}
$$

where $A_{0}$ is the intercept, the $A_{1}-A_{4}$ parameters describe the ozone seasonal cycle, $A_{5}$ is the annual trend, $X_{k}(t)$ are the explanatory variables (proxies time series) and $A_{k}$ their respective coefficient, and $\epsilon(t)$ represents the residuals.

To select the final regression model, we have included several proxies, which represent processes that are known to impact ozone, in a stepwise regression procedure that keeps or rejects each proxy: the initial model (seasonal cycle and trend) is fitted first. Second, iteratively, if any proxies, not already in the model, have $p$ values smaller than an entrance tolerance $(0.05)$, i.e., if it is unlikely that they would have a 0 coefficient if added to the model, then we add the one with the smallest $p$ value. Otherwise, if any proxies in the model have $p$ values greater than an exit tolerance $(0.10)$, we remove the one with the largest $p$ value and we repeat the whole process until no single step improves the model. Hence, the final set of parameters can vary with the station and with the partial columns concerned. In this paper, a proxy is called "non-significant" when it has not been retained by the stepwise procedure. This choice of not using a fixed model for all stations and partial columns avoids overfitting the data and is justified by the large latitudinal range of the stations (e.g., the VPSC or ENSO proxies will not impact the stations in the same way) and by the different processes driving ozone variability at different altitudes.

The proxies that have been tested in the stepwise regression procedure are summarized in Table 4. The two most common explanatory variables found in the literature are the solar radio flux at $\mathrm{F} 10.7 \mathrm{~cm}$ (SOLAR) which represents the 11-year solar cycle (following e.g., Newchurch et al., 2003; Randel and Wu, 2007), and the zonal winds measured at Singapore at 30 and $10 \mathrm{hPa}$ (following e.g., Brunner et al., 2006) which represent the quasi-biennial oscillation (QBO). The proxy used for the El Niño-Southern Oscillation (ENSO) is the multivariate ENSO index (MEI), following Randel et al. (2009). Different time lags (from 0 to 4 months) between ENSO and ozone time series have been tested. The other dynamical proxies that have been explored are the tropopause pressure (TP) at each station (following e.g., Appenzeller et al., 2000), the equivalent latitude (EL) at three altitude levels around each station, the Arctic Oscillation (AO) or the Antarctic Oscillation (AAO) indices depending on the station location (e.g., Appenzeller et al., 2000; Frossard et al., 2013), and the vertical component of the Eliassen-Palm flux (EPF) at $100 \mathrm{hPa}$ averaged over $45-75^{\circ}$ north and south, as a proxy for the Brewer-Dobson circulation (e.g., Brunner et al., 2006). These dynamical proxies are connected, e. g. the 

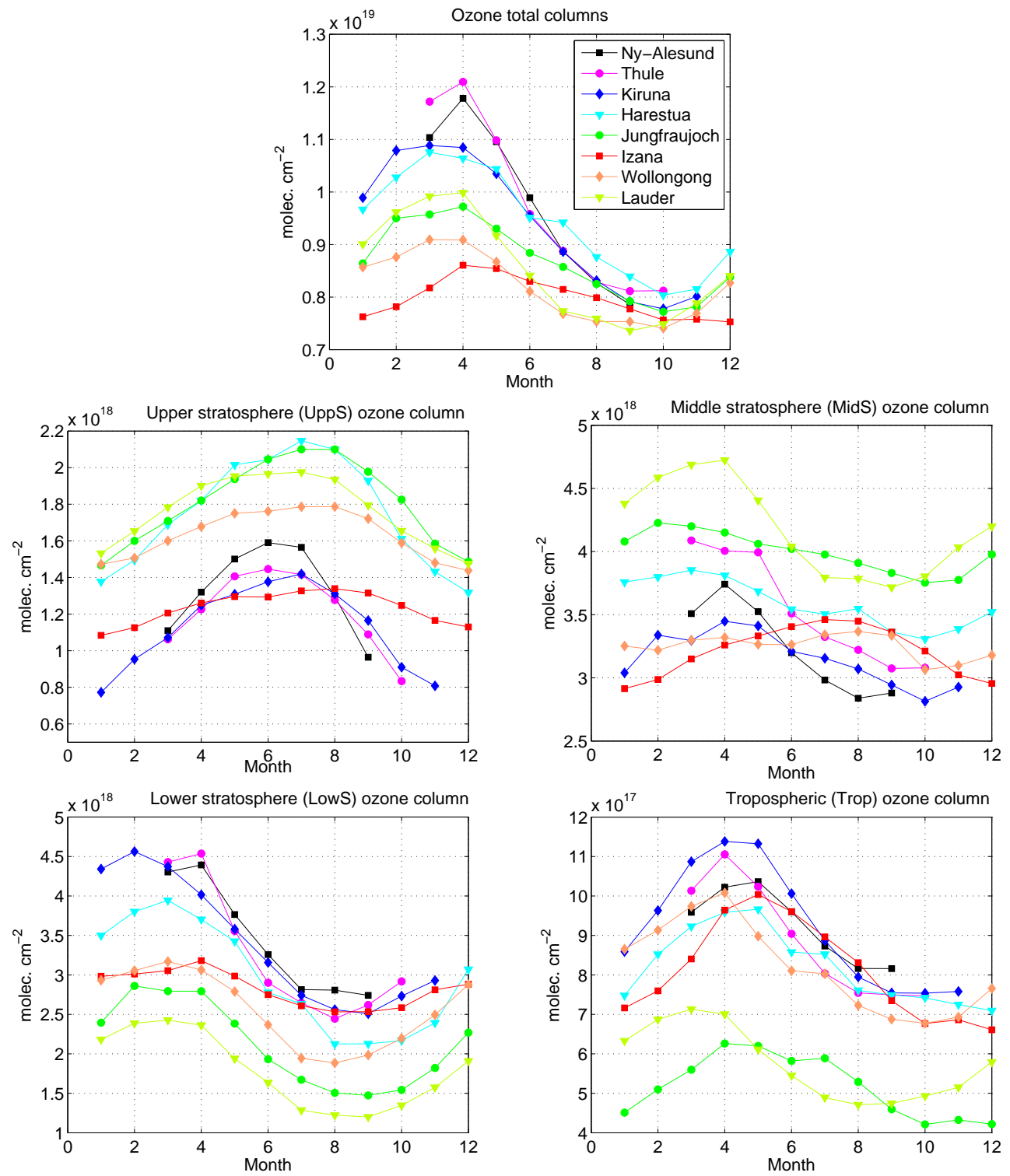

Figure 3. Monthly means of ozone total and partial columns for the whole periods of measurements. See Table 3 for the limits of the partial columns at each station. The seasonal cycle for Southern Hemisphere stations, Wollongong and Lauder, has been shifted by 6 months for better comparison.

NAO (North Atlantic Oscillation, closely related to $\mathrm{AO}$ ) and the tropopause pressure (Appenzeller et al., 2000), the eddy heat flux (proportional to EPF) and the AO (Weber et al., 2011), but we let the stepwise regression model choose the most adapted proxy for each station and partial column. Concerning the equivalent latitude, we did not construct an integrated equivalent proxy valuable for the whole ozone "integrated" total column as in Wohltmann el al. (2005). Here, we simply use the equivalent latitude calculated from ERA Interim reanalysis (Dee et al., 2011) at three altitude levels corresponding approximately to the middle of our three stratospheric layers (ELL for LowS, ELM for MidS, and ELU for UppS; see Table 3 for the layer limits), namely at 370, 550, and $950 \mathrm{~K}$, respectively, for all stations except Izaña and Wollongong (460, 700, and $1040 \mathrm{~K}$, respectively).

Lastly, the volume of polar stratospheric clouds (VPSC) is used as a proxy for polar ozone loss (e.g., Brunner et al., 2006). The VPSC proxy has been multiplied by the effective equivalent stratospheric chlorine (EESC) time series calculated with a mean age of air of 5.5 years, in order to take into account the time for the ozone-depleting substances to reach the poles (http://acdb-ext.gsfc.nasa.gov/Data_services/ automailer/index.html). To account for the cumulative effect over months of the EPF and the VPSC*EESC proxies on ozone, we have followed the approach of Brunner et al. 
Table 4. Name, short description, and source of the proxies that have been tested in the stepwise regression model.

\begin{tabular}{|c|c|c|}
\hline Name & Description & Source \\
\hline SOLAR & solar radio flux at $10.7 \mathrm{~cm}$ & $\begin{array}{l}\text { ftp://ftp.ngdc.noaa.gov/STP/SOLAR_DATA/SOLAR_RADIO } \\
\text { /FLUX/Penticton_Adjusted/monthly/MONTHLY.ADJ }\end{array}$ \\
\hline QBO30 & zonal winds measured at Singapore at $30 \mathrm{hPa}$ & http://www.geo.fu-berlin.de/en/met/ag/strat/produkte/qbo/index.html \\
\hline QBO10 & zonal winds measured at Singapore at $10 \mathrm{hPa}$ & http://www.geo.fu-berlin.de/en/met/ag/strat/produkte/qbo/index.html \\
\hline ENSO & multivariate ENSO index (MEI) & http://www.esrl.noaa.gov/psd/enso/mei/ \\
\hline \multirow[t]{2}{*}{$\mathrm{AO} / \mathrm{AAO}$} & Arctic Oscillation & $\begin{array}{l}\text { http://www.cpc.ncep.noaa.gov/products/precip/CWlink/daily_ao_index } \\
\text { /monthly.ao.index.b50.current.ascii }\end{array}$ \\
\hline & Antarctic Oscillation & $\begin{array}{l}\text { http://www.cpc.ncep.noaa.gov/products/precip/CWlink/daily_ao_index } \\
\text { /aao/monthly.aao.index.b79.current.ascii }\end{array}$ \\
\hline ТP & tropopause pressure & $\begin{array}{l}\text { http://www.esrl.noaa.gov/psd/data/gridded } \\
\text { /data.ncep.reanalysis.tropopause.html }\end{array}$ \\
\hline EL(L/M/U) & $\begin{array}{l}\text { equivalent latitude at three altitude levels: } \\
\text { 370, 550, and } 950 \mathrm{~K}: \text { high-/mid-latitude stations } \\
460,700 \text {, and } 1040 \mathrm{~K} \text { : subtropical stations }\end{array}$ & calculated at BIRA from ERA interim reanalysis \\
\hline EPF & vertical component of the EP flux & $\begin{array}{l}\text { http://www.awi.de/en/research/research_divisions/climate_science } \\
\text { /atmospheric_circulations/projects/candidoz/ep_flux_data/ }\end{array}$ \\
\hline VPSC & volume of polar stratospheric clouds & calculated at FMI \\
\hline
\end{tabular}

(2006) (see their Eq. 4), with the same dependence of their constant $\tau$ on season and latitude of the station.

For the two QBO proxies ( 30 and $10 \mathrm{hPa}$ ), if retained in the stepwise procedure, four seasonal parameters can be added to the model. The $A_{k} \cdot X_{k}(t)$ term of Eq. (2) is then replaced by

$$
\begin{aligned}
& \left(A_{k}+A_{k+1} \cdot \cos (2 \pi t / 12)+A_{k+2} \cdot \sin (2 \pi t / 12)\right. \\
& \left.+A_{k+3} \cdot \cos (4 \pi t / 12)+A_{k+4} \cdot \sin (4 \pi t / 12)\right) \cdot X_{k}(t) .
\end{aligned}
$$

Depending on the station and on the layer, none, one or both of the two proxies QBO30 and QBO10 will be retained in the model, with or without their additional seasonal parameters. We will call from here on "QBO contribution" the sum of all possible contributions of QBO30 and QBO10.

Since the time series involved in the present study start at the earliest in 1995, we do not include two commonly used explanatory variables: the aerosol optical thickness needed to represent the effect on ozone of the large volcanic eruptions of El Chichón (1982) and Mount Pinatubo (1991), and the EESC proxy which can be used as direct proxy for the halogen loading of the stratosphere instead of the piecewise linear trend (PWLT) with a turnaround in 1996/1997 often used in time series starting well before this turnaround point (WMO, 2010). Our linear-trend estimates are therefore better comparable to the studies which use the PWLT method. At polar stations, the turnaround is occurring a few years later, so that the use of the EESC proxy could be an alternative to the simple linear trend for these stations. However, we preferred to adopt the same approach for all the stations. It is possible that when the FTIR record is longer, one will be able to distinguish between the EESC impact on ozone and a possible additional trend due to processes that are not represented in the model.

\section{Results and discussion}

In Fig. 4, we show the individual contribution $C_{\text {frac }}$ of each proxy retained by the stepwise procedure to the coefficient of determination $R^{2}=\sum C_{\text {frac }}$, for each station and partial column. The individual contribution $C_{\text {frac }}$ of a proxy is the product of the standardized regression coefficient of this proxy with the correlation coefficient between the proxy and the observations (Scherrer, 1984). In Fig. 4, the seasonal parameters' contribution $\left(A_{1}-A_{4}\right.$ in Eq. 2$)$, which gives in most cases the very dominant part of the explained variability, is not shown for better clarity of the other proxies' contribution. However, we give it for completeness in Table 5, together with $R^{2}$. In the following discussion, we will highlight some selected features which are visible in the ozone time series and which can be attributed to a specific proxy. The final MLR model is the sum of all the significant proxies and, therefore, the effect of a specific proxy can be visible in the plots in some years, but masked in other years.

In Table 6, we give the annual ozone trend at each station for each layer obtained with the stepwise multiple linear regression model. The uncertainties on the trends correspond to the $95 \%$ confidence interval. A trend is considered significant if it is larger than the uncertainty.

\subsection{High latitude stations}

In addition to the three Arctic stations Ny- $\AA$ lesund, Thule and Kiruna, we will consider Harestua $\left(60^{\circ} \mathrm{N}\right)$ as a high latitude station since, in terms of trends, Harestua appears to behave similarly to the Arctic stations. 

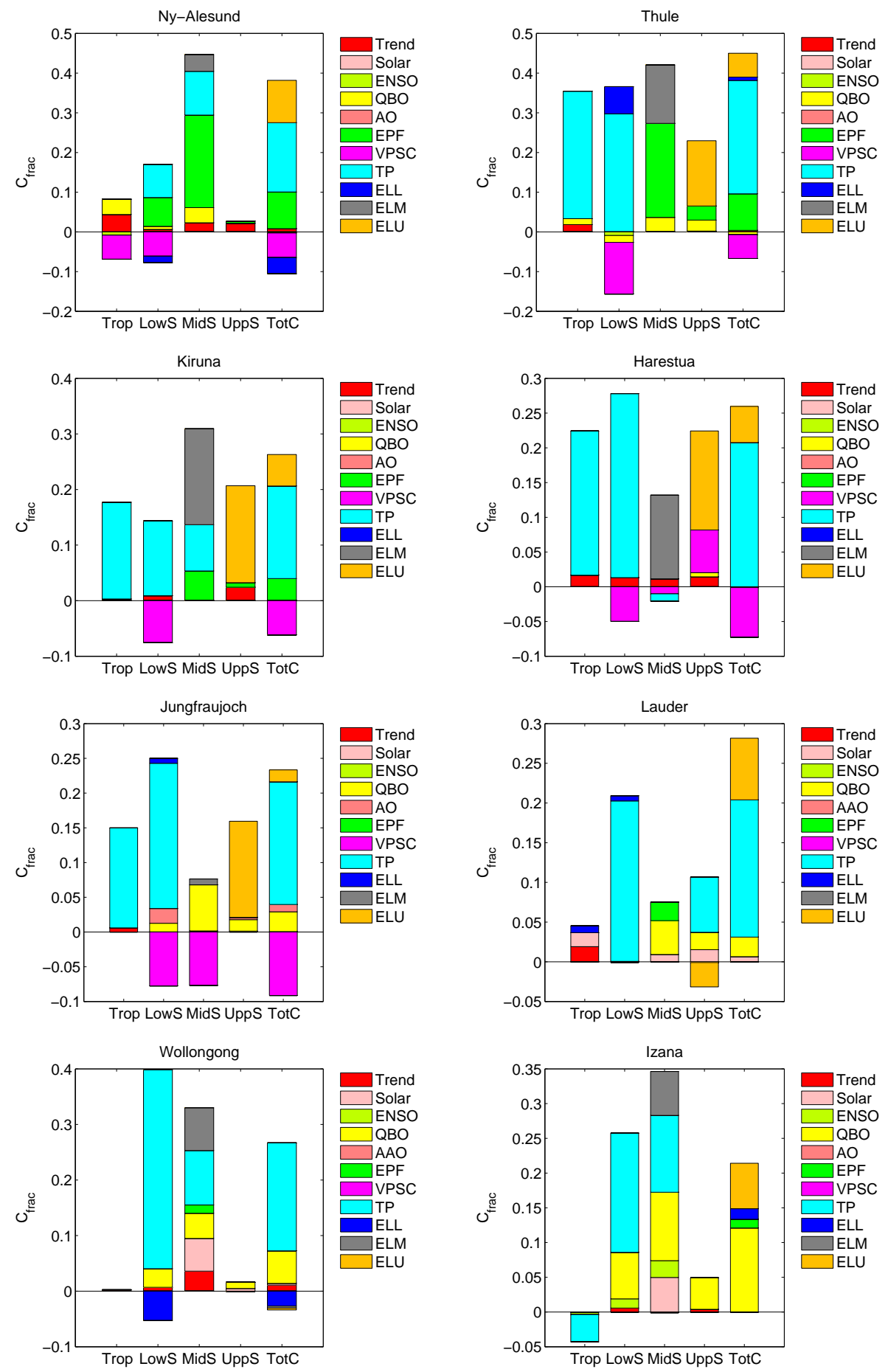

Figure 4. Individual contributions $C_{\text {fract }}$ of the proxies to the coefficient of determination $R^{2} \cdot R^{2}$ and the dominant contribution of the seasonal cycle $C_{\text {seas }}$ are given in Table 5 .

\subsubsection{Tropospheric (Trop) columns}

In the troposphere, the high latitude stations, except Kiruna, show negative significant ozone trends (Table 6). The spatial and temporal variability in the Arctic and the different sampling at the stations Thule/Ny-Ålesund due to polar night (see Fig. 2) makes it difficult to compare the trend results. We see in Fig. 5 that at Ny-Ålesund the negative trend occurs in the second part of the period (2004-2012), which is also observed at Thule (not shown). On the contrary, at Harestua, the 
Table 5. Coefficient of determination $R^{2}$ and contribution of the seasonal cycle $C_{\text {seas }}$ determined within the final model. See Table 3 for the limits of the layers, different for subtropical stations and mid-/high-latitude stations.

\begin{tabular}{lrrrrr}
\hline FTIR station & Trop & LowS & MidS & UppS & Total columns \\
\hline Ny-Ålesund & $R^{2}=0.75$ & $R^{2}=0.92$ & $R^{2}=0.72$ & $R^{2}=0.74$ & $R^{2}=0.95$ \\
& $C_{\text {seas }}=0.73$ & $C_{\text {seas }}=0.82$ & $C_{\text {seas }}=0.27$ & $C_{\text {seas }}=0.72$ & $C_{\text {seas }}=0.68$ \\
Thule & $R^{2}=0.86$ & $R^{2}=0.92$ & $R^{2}=0.83$ & $R^{2}=0.81$ & $R^{2}=0.96$ \\
& $C_{\text {seas }}=0.50$ & $C_{\text {seas }}=0.71$ & $C_{\text {seas }}=0.41$ & $C_{\text {seas }}=0.58$ & $C_{\text {seas }}=0.58$ \\
Kiruna & $R^{2}=0.85$ & $R^{2}=0.89$ & $R^{2}=0.54$ & $R^{2}=0.78$ & $R^{2}=0.89$ \\
& $C_{\text {seas }}=0.67$ & $C_{\text {seas }}=0.82$ & $C_{\text {seas }}=0.23$ & $C_{\text {seas }}=0.58$ & $C_{\text {seas }}=0.69$ \\
Harestua & $R^{2}=0.77$ & $R^{2}=0.74$ & $R^{2}=0.36$ & $R^{2}=0.67$ & $R^{2}=0.75$ \\
& $C_{\text {seas }}=0.54$ & $C_{\text {seas }}=0.51$ & $C_{\text {seas }}=0.25$ & $C_{\text {seas }}=0.45$ & $C_{\text {seas }}=0.56$ \\
Jungfraujoch & $R^{2}=0.73$ & $R^{2}=0.83$ & $R^{2}=0.53$ & $R^{2}=0.93$ & $R^{2}=0.81$ \\
& $C_{\text {seas }}=0.58$ & $C_{\text {seas }}=0.66$ & $C_{\text {seas }}=0.53$ & $C_{\text {seas }}=0.77$ & $C_{\text {seas }}=0.67$ \\
Izaña & & & & & \\
& $R^{2}=0.83$ & $R^{2}=0.72$ & $R^{2}=0.80$ & $R^{2}=0.69$ & $R^{2}=0.77$ \\
Wollongong & $C_{\text {seas }}=0.87$ & $C_{\text {seas }}=0.46$ & $C_{\text {seas }}=0.45$ & $C_{\text {seas }}=0.64$ & $C_{\text {seas }}=0.56$ \\
& $R^{2}=0.69$ & $R^{2}=0.86$ & $R^{2}=0.42$ & $R^{2}=0.77$ & $R^{2}=0.87$ \\
& $C_{\text {seas }}=0.69$ & $C_{\text {seas }}=0.52$ & $C_{\text {seas }}=0.09$ & $C_{\text {seas }}=0.75$ & $C_{\text {seas }}=0.63$ \\
& & & & & \\
Lauder & $R^{2}=0.89$ & $R^{2}=0.94$ & $R^{2}=0.78$ & $R^{2}=0.89$ & $R^{2}=0.95$ \\
& $C_{\text {seas }}=0.85$ & $C_{\text {seas }}=0.73$ & $C_{\text {seas }}=0.70$ & $C_{\text {seas }}=0.82$ & $C_{\text {seas }}=0.66$ \\
\hline
\end{tabular}

Table 6. Annual trend (in $\%$ decade $^{-1}$ ) and their $95 \%$ uncertainty ranges. Due to polar night, the measurements at Ny-Ålesund, Thule and Kiruna cover only the mid-March-September, late-February-mid-October, and mid-January-mid-November periods, respectively. All time series end in September/December 2012 for the present study. The time of start is repeated for each station. See Table 3 for the limits of the layers, different for subtropical stations and mid-/high-latitude stations. Trends indicated in bold are significant.

\begin{tabular}{lrrrrr}
\hline FTIR station & Trop & LowS & MidS & UppS & Total columns \\
\hline $\begin{array}{l}\text { Ny-Ålesund } \\
1995\end{array}$ & $\mathbf{- 5 . 8} \pm \mathbf{3 . 2}$ & $\mathbf{- 4 . 2} \pm \mathbf{3 . 1}$ & $\mathbf{- 5 . 5} \pm \mathbf{3 . 8}$ & $\mathbf{+ 6 . 7} \pm \mathbf{5 . 3}$ & $-\mathbf{3 . 0} \pm \mathbf{1 . 5}$ \\
$\begin{array}{l}\text { Thule } \\
1999 \text { (October) }\end{array}$ & $-\mathbf{5 . 3} \pm \mathbf{4 . 4}$ & $-0.4 \pm 6.3$ & $+0.2 \pm 4.4$ & $-2.3 \pm 6.5$ & $-2.1 \pm 2.6$ \\
$\begin{array}{l}\text { Kiruna } \\
1996\end{array}$ & $-0.9 \pm 2.5$ & $\mathbf{- 3 . 9} \pm \mathbf{2 . 6}$ & $+0.4 \pm 2.6$ & $\mathbf{+ 7 . 4} \pm \mathbf{3 . 4}$ & $-0.3 \pm 1.6$ \\
$\begin{array}{l}\text { Harestua } \\
1995\end{array}$ & $\mathbf{- 3 . 1} \pm \mathbf{2 . 0}$ & $\mathbf{- 5 . 3} \pm \mathbf{4 . 6}$ & $\mathbf{+ 4 . 8} \pm \mathbf{4 . 3}$ & $\mathbf{+ 7 . 8} \pm \mathbf{5 . 5}$ & $+1.0 \pm 2.2$ \\
$\begin{array}{l}\text { Jungfraujoch } \\
1995\end{array}$ & $-2.5 \pm 2.7$ & $-0.5 \pm 3.3$ & $-0.6 \pm 1.2$ & $+0.9 \pm 1.0$ & $-0.4 \pm 1.2$ \\
$\begin{array}{l}\text { Izaña } \\
1999\end{array}$ & $+0.7 \pm 2.8$ & $-1.7 \pm 2.2$ & $-0.1 \pm 2.0$ & $+1.6 \pm 2.6$ & $+0.5 \pm 1.2$ \\
$\begin{array}{l}\text { Wollongong } \\
\text { 1996 }\end{array}$ & $-2.2 \pm 2.8$ & $\mathbf{+ 3 . 1} \pm \mathbf{2 . 7}$ & $\mathbf{+ 4 . 0} \pm \mathbf{2 . 0}$ & $+0.2 \pm 1.6$ & $+\mathbf{1 . 9} \pm \mathbf{1 . 1}$ \\
$\begin{array}{l}\text { Lauder with / } \\
\text { without SOLAR }\end{array}$ & $\mathbf{+ 7 . 7} \pm \mathbf{3 . 5}$ & $-3.8 \pm 4.1$ & $-0.2 \pm 3.5$ & $\mathbf{+ 2 . 8} \pm \mathbf{2 . 4}$ & $-0.3 \pm 1.8$ \\
2001 & & - & $-1.1 \pm 3.4$ & $+1.7 \pm 2.4$ & $-0.6 \pm 1.9$ \\
\hline
\end{tabular}

negative trend is occurring in the 1999-2007 period (Fig. 5, lower left panel). The second line of Fig. 5 shows the partial columns where the seasonal cycle is removed to emphasize the interannual variability, and the effect of individual proxies showing interannual differences. We have added in the third line of Fig. 5 the VPSC signal, i.e., the VPSC proxy 
time series multiplied by the corresponding parameter obtained in the MLR process $\left(A_{k} \cdot X_{k}(t)\right.$ in Eq. 2). We see that the particular low tropospheric values in 1995, 2005 and 2011 at Ny-Ålesund can be related to the VPSC proxy and, therefore, by the influence of lower stratospheric ozone variability on the tropospheric columns. At the three other stations, this VPSC impact was not found to be significant, and the main driver of tropospheric variability is found to be the tropopause pressure TP (Fig. 4). The larger VPSC value in 1996 does not lead to a larger decrease in tropospheric ozone because it is compensated by a positive QBO signal, while the small ozone value in 2004 is related to a negative QBO signal (not shown).

As expected, the large VPSC values in 1995, 2005 and 2011 have also a significant impact on the lower stratospheric (LowS) values at Ny-Ålesund (middle column of Fig. 5), as well as in 1996, since the negative effect is not compensated by the QBO signal as in Trop. We can note that the VPSC impact is 10 times larger in LowS than in Trop (different scales in Fig. 5).

\subsubsection{Lower stratospheric (LowS) columns}

The VPSC proxy is found significant at the four high latitude stations for the lower stratospheric columns, being the main driver of ozone variability after TP (Fig. 4). We give the example of Ny-Ålesund and Kiruna in Fig. 5, where the effect of large amount of VPSC in 1996, 2005, and 2011 is clearly visible in both monthly means and deseasonalized time series. We show in addition the EPF and TP signals at NyÅlesund and Kiruna, respectively, in the bottom panel. It can be seen that the TP signal at Kiruna in 2005 also contributed to even lower ozone that particular year. The larger LowS values at Ny-Ålesund in 1999 are due to a combination of the TP (not shown) and EPF signals.

In the lower stratosphere, at all high latitude stations, except Thule, we observe significant negative trends (Table 6). At Thule, the shorter time period associated with the high variability of this layer at high latitude gives a large uncertainty on the trend.

\subsubsection{Middle stratospheric (MidS) columns}

The results are mixed for the middle stratospheric layers, as noticed previously for the seasonal cycles. The trend is significantly negative at Ny-Ålesund and non-significant at Thule. The trend is non-significant at Kiruna, and significantly positive at Harestua. The EPF proxy explains about $25 \%$ of the variability at Ny-Ålesund and Thule, and about $5 \%$ at Kiruna (Fig. 4). This is illustrated in Fig. 6 for NyÅlesund and Thule, where we see nicely the same features at both stations in the middle stratospheric columns (e.g., higher columns in 2009, 2010; lower columns in 2011), associated with the EPF time series.

\subsubsection{Upper stratospheric (UppS) columns}

In the upper stratosphere, the three stations with similar time periods show a significant positive trend. In the three cases, the increase in ozone partial columns occurs in the 19952003 period, after which a leveling off is observed (Fig. 7). If we run the MLR model on the same time period as Thule (October 1999-2012), all the stations show non-significant trends. Since the EESCs were still increasing until about 2000 at polar regions (WMO, 2010), the significant positive trends obtained at high latitude stations in the upper stratosphere cannot be explained by the effect of the Montreal Protocol on ozone depleting substances. At present we do not have an explanation for this increase in ozone during the 1995-2003 period. The 11-year solar cycle might contribute to it, since the increase in solar activity from 1996 to its maximum in 2001-2002 is in phase with the ozone increase during the same period. The solar cycle signal at NyÅlesund, shown in Fig. 7 as an illustration, turns out to be non-significant after the Cochrane-Orcutt transformation is applied, so its contribution is small and not visible in Fig. 4. The solar cycle might be found non-significant at the other stations because the expected decrease of ozone during the declining phase of the solar cycle (2002-2009) is not observed. This could be a sign that this decrease is compensated by a positive linear trend, which could be due to the declining EESCs, but also to the increase of greenhouse gases (WMO, 2010). More years are needed to understand unequivocally the increase in 1995-2003, followed by a leveling off, and distinguish between the ozone responses due to solar cycle, EESCs and other possible proxies not included in the present study.

\subsubsection{Total columns}

We observe that the total column ozone trends are small and non-significant at all high latitude stations, except at Ny-Ålesund $\left(-3.0 \pm 1.5 \% \mathrm{decade}^{-1}\right.$ or $-10.8 \pm 5.6 \mathrm{DUdecade}^{-1}$ ). The negative trend at $\mathrm{Ny}-$ Ålesund occurs in the 2003-2012 period, as for the lowest altitude layers. At all stations, the dominant contributions to the total column variability are the TP, the VPSC, the ELU, and, except at Harestua, the EPF proxies. We see nicely in Table 5, how well the proxies explained the additional variability at the Arctic stations, e.g., at Ny-Ålesund $R^{2}=0.95$, compared to the contribution of the seasonal cycle $C_{\text {seas }}=0.68$.

\subsection{Mid-latitude and subtropical stations}

In this study, we have two mid-latitude stations (Jungfraujoch at $47^{\circ} \mathrm{N}$ and Lauder at $45^{\circ} \mathrm{S}$ ) and two subtropical stations (Izaña at $28^{\circ} \mathrm{N}$ and Wollongong $34^{\circ} \mathrm{S}$ ). 

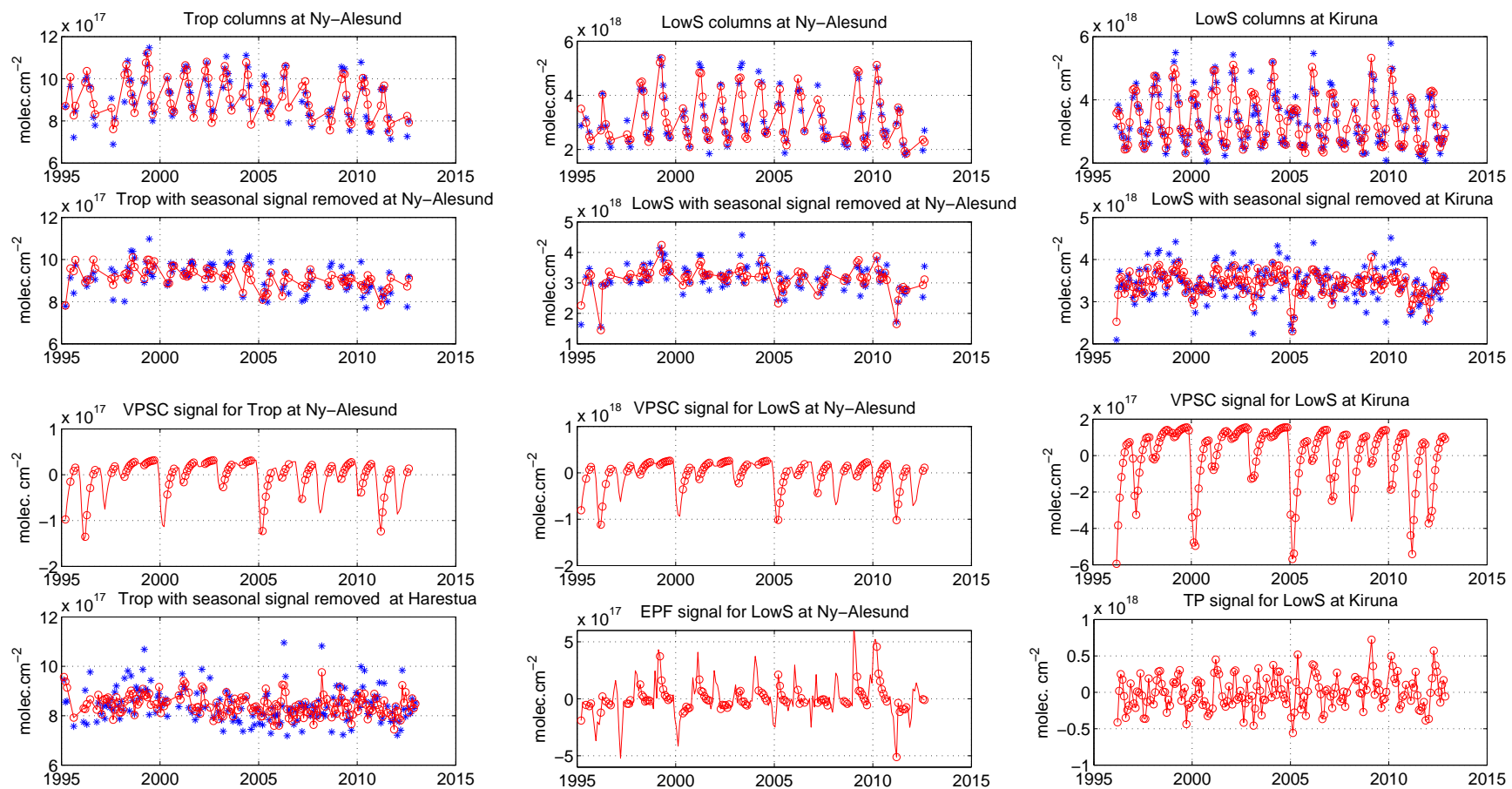

Figure 5. Left (top to bottom panels): (1) monthly means of the tropospheric columns (Trop) at Ny-Ålesund (blue: FTIR, red: MLR model); (2) same but with the seasonal signal removed; (3) the VPSC signal obtained from the MLR model for Trop at Ny-Ålesund, for each month of the period (red line), and at each FTIR observed month (red circle); (4) monthly means of Trop at Harestua with the seasonal cycle removed. Middle panels: (1-3) same as left panels but for the lower stratospheric columns (LowS) at Ny-Ålesund; (4) the EPF signal obtained for the LowS at Ny-Ålesund. Right panels: (1-3) same as middle panels but at Kiruna; (4) the tropopause pressure (TP) signal obtained for the LowS at Kiruna.
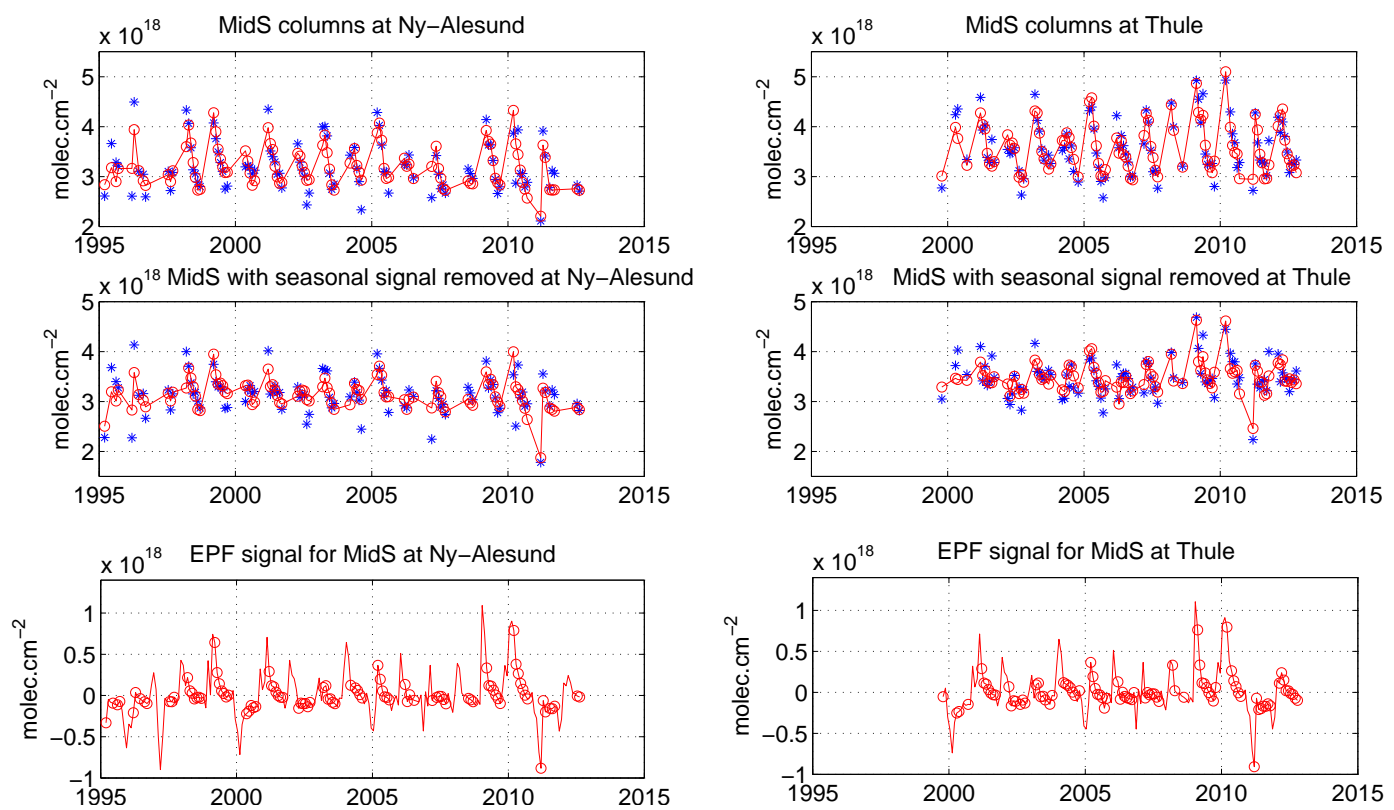

Figure 6. Top panels: monthly means of the middle stratospheric columns (MidS) at Ny-Ålesund (left) and Thule (right) (blue: FTIR, red: MLR model). Middle panels: same but with the seasonal signal removed. Bottom panels: the EPF signal obtained in each case from the MLR model, for each month of the period (red line), and at each FTIR observed month (red circle). 

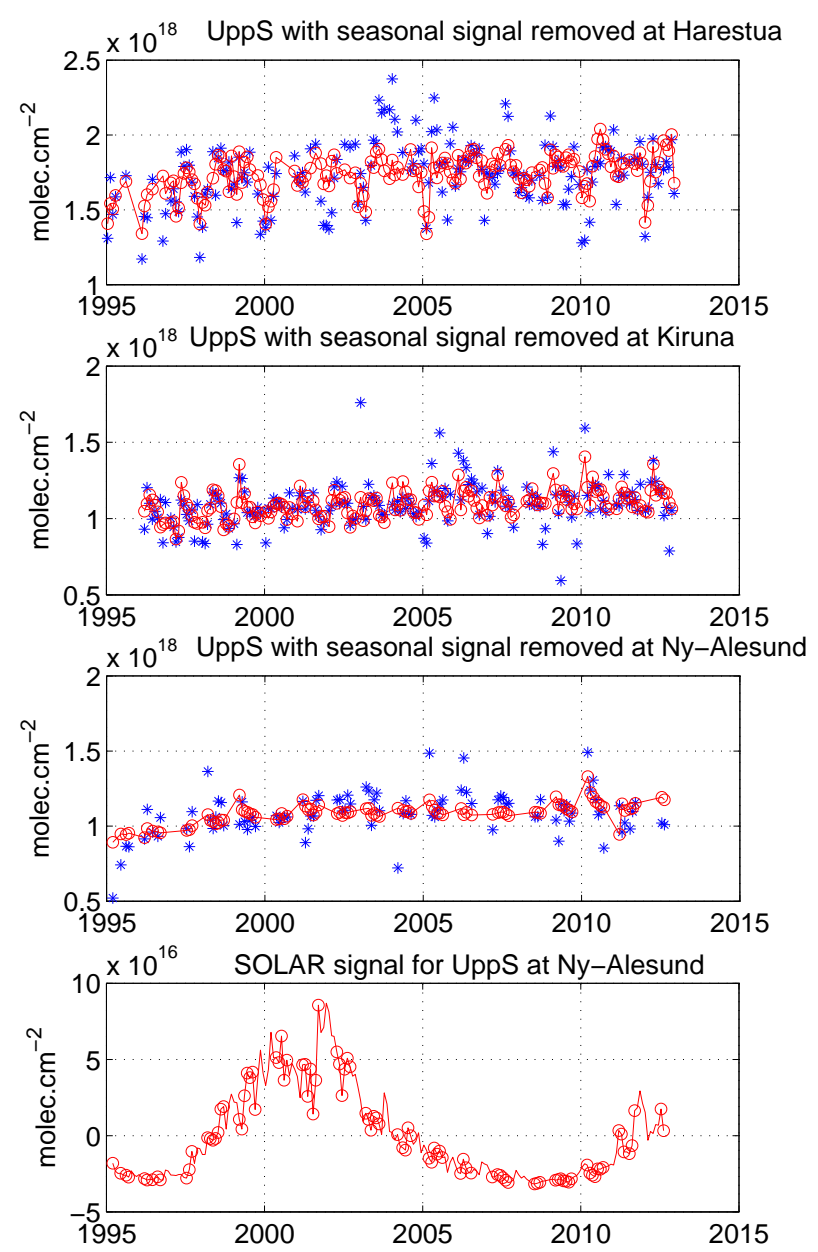

Figure 7. Monthly means of the upper stratospheric columns (UppS) with the seasonal cycle removed at, from top to bottom: Harestua, Kiruna and Ny-Ålesund (blue: FTIR, red: MLR model). Bottom panel: the solar cycle signal obtained at $\mathrm{Ny}$-Ålesund from the MLR model, before the Cochrane-Orcutt transformation.

\subsubsection{Tropospheric (Trop) columns}

The tropospheric trends are non-significant at Jungfraujoch, Izaña and Wollongong, and significantly positive at Lauder. The trend at Jungfraujoch is $-2.5 \pm 2.7 \%$ decade $^{-1}$; however, we see in Fig. 8 that the tropospheric columns are increasing up to 1999 and then show a linear decrease, in agreement with aircraft and surface alpine sites in the study of Logan et al. (2012). If we limit our time period to the 19982008 period as in Logan et al. (2012), we also find a significant negative trend $\left(-6.3 \pm 4.9 \%\right.$ decade $\left.^{-1}\right)$. However, this is largely due to the high ozone values 1998-1999, and for the period 2000-2012 we obtain still a non-significant trend of $-2.9 \pm 3.4 \%$ decade $^{-1}$. At Izaña, the tropospheric trends derived from ozonesondes were found non-significant in García et al. (2012), in agreement with our study, but the uncertainties were large. The situation is more mixed in the Southern Hemisphere: the tropospheric trend at Wollongong is not significant while it is significantly positive at Lauder $\left(+7.7 \pm 3.5 \%\right.$ decade $\left.^{-1}\right)$. The trend at Lauder is in agreement with the study of Oltmans et al. (2013), who obtain about $+5 \%$ decade $^{-1}$ in the lower and middle troposphere with ozonesonde measurements at Lauder. We find a significant positive impact of the solar cycle at Lauder and it is clearly seen in Fig. 8. This is not in agreement with Chandra et al. (1999), in which the solar cycle shows a strong but negative impact on tropospheric columns for a non-polluted region. At Lauder, presently only a short time period (2001-2012) is available for trend studies, and we hope to have more clarification on this subject with more years of data. However, if we remove the solar cycle proxy from the MLR model, we still obtain a significant trend of $+5.0 \pm 4.4 \% \mathrm{decade}^{-1}$. For this short time series, we have added in Table 6 the trends that are obtained if the solar cycle is removed from the model.

\subsubsection{Lower stratospheric (LowS) columns}

The trends in the lower stratosphere are non-significant at Jungfraujoch, Izaña and Lauder, and significantly positive at Wollongong. The cause of the significant positive trend at Wollongong is not fully explained at present. A part of it is due to a small negative trend in the ELL proxy. If we remove this proxy from the MLR model, we observe a nonsignificant positive trend of $+2.4 \pm 2.8 \%$ decade $^{-1}$.

The dominant proxy is TP for all stations. At the Jungfraujoch station, the VPSC proxy, which in the case of Jungfraujoch corresponds to the transport of polar ozone loss to midlatitudes, explains about $8 \%$ of the variability (Fig. 4). The VPSC proxy is non-significant at the southern hemispheric station Lauder, in agreement with the more stable and isolated vortex in the Antarctic compared to the Arctic. The AO proxy is found significant at Jungfraujoch while the corresponding AAO proxy is non-significant at Lauder.

We show the time series of the lower stratospheric columns at Jungfraujoch in Fig. 9 together with the $\mathrm{AO}$ and QBO signals. We see that in 2010 ozone shows larger values and that this is explained by the combination of a very negative $\mathrm{AO}$ index (the corresponding parameter in the MLR is negative and gives the positive signal in 2010 shown in Fig. 9) and easterly phase of the QBO. This is in agreement with Nair et al. (2013), who applied a MLR model to the mean of ozone anomalies at Observatoire de Haute-Provence (OHP) from different instruments (lidar, ozonesondes and satellites). However, we did not find a significant contribution from the EPF proxy, which according to Nair et al. (2013) also contributed to the high ozone values in 2010 . We can state that our vertical and total column ozone trends are in agreement with the Nair et al. (2013) results when taking the error bars into account, but the latter study found significant positive trends at OHP while our trends at Jungfraujoch are all non-significant.

As expected, the QBO contribution to ozone variability is more important at the subtropical station Izaña, which is 

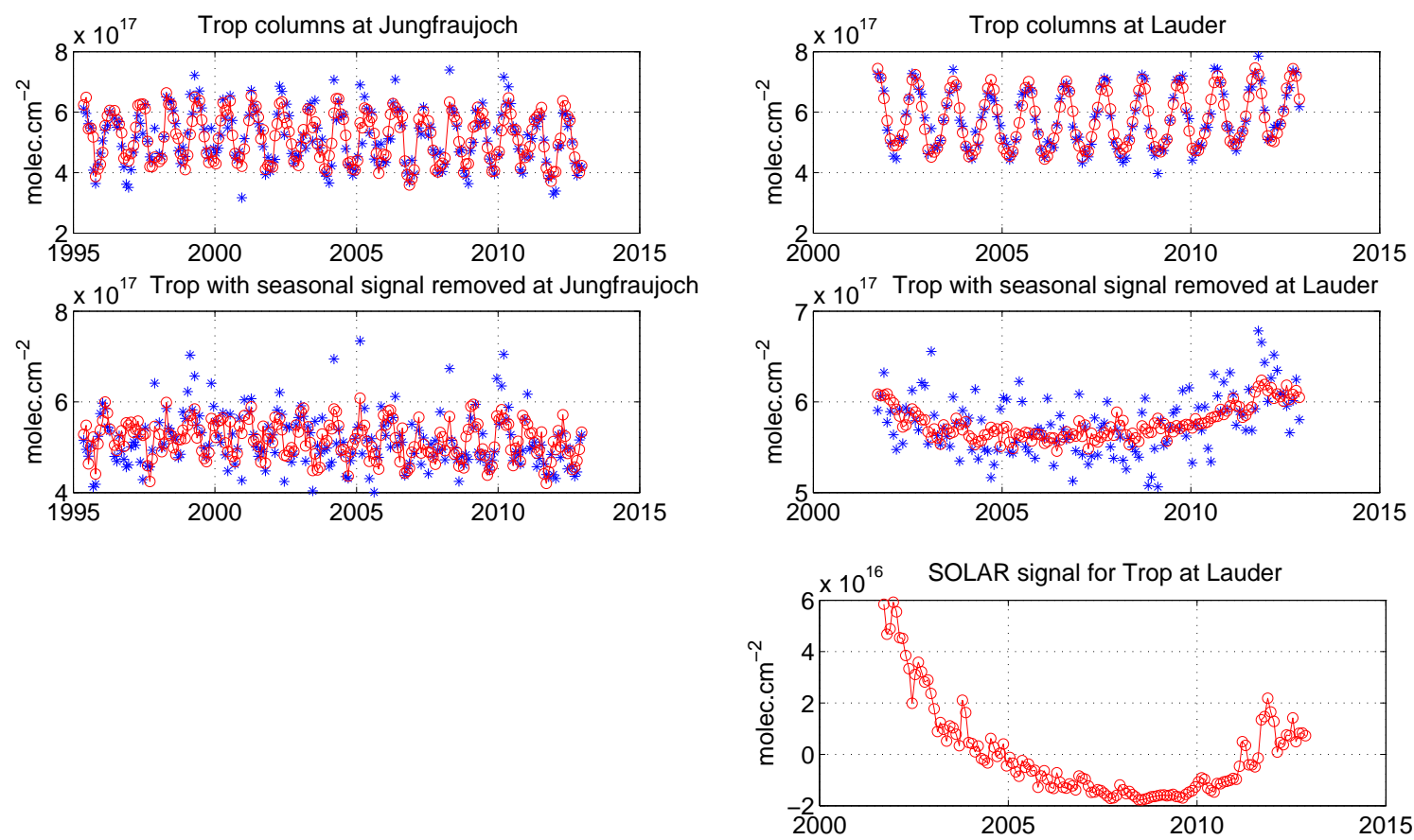

Figure 8. Top panels: monthly means of the tropospheric columns (Trop) at Jungfraujoch (left) and Lauder (right) (blue: FTIR, red: MLR model). Middle panels: same but with the seasonal signal removed. Bottom panel: the solar cycle signal obtained at Lauder from the MLR model.
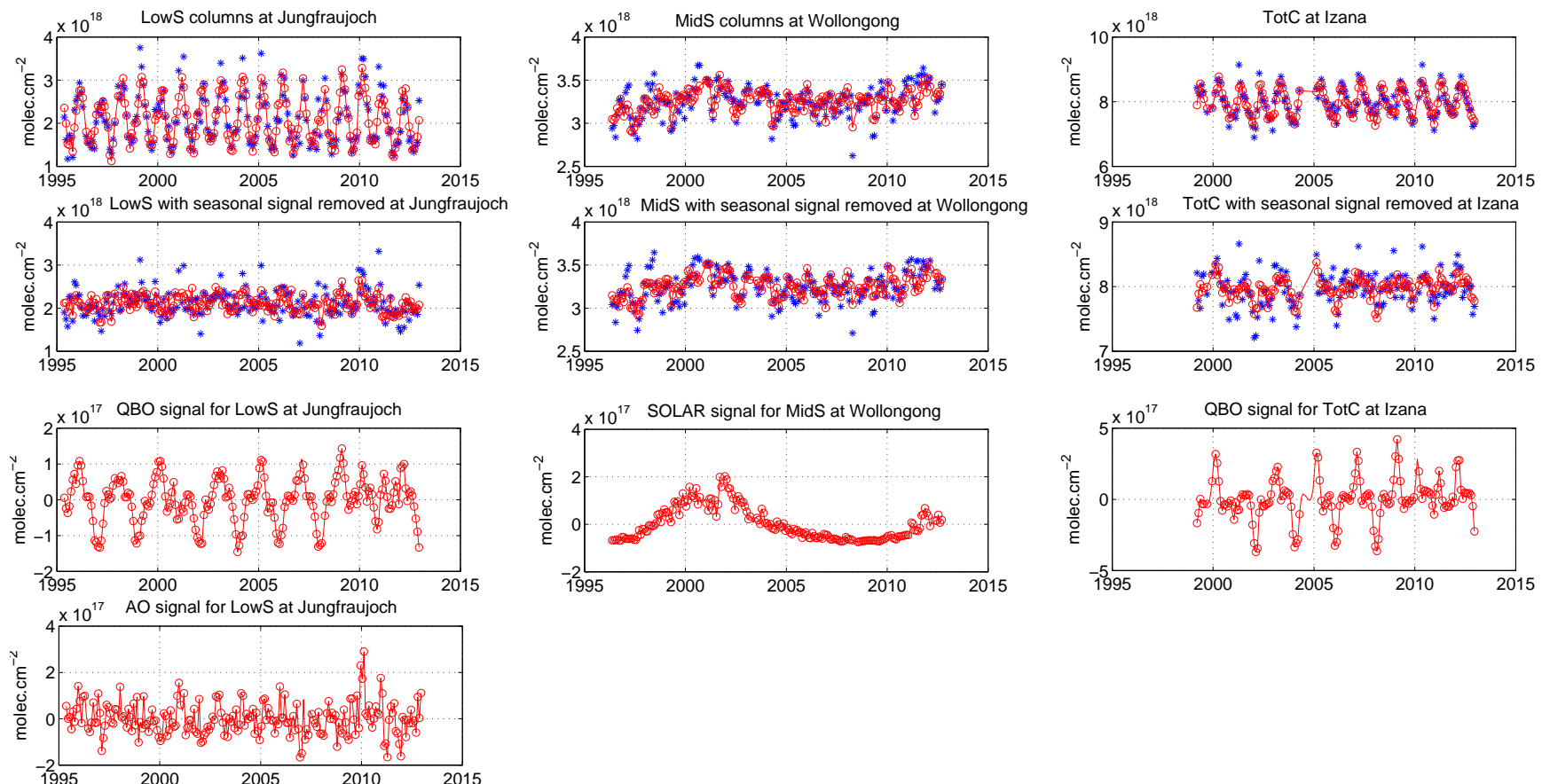

Figure 9. Top panels: monthly means of the lower stratospheric columns (LowS) at Jungfraujoch (left), middle stratospheric columns (MidS) at Wollongong (middle), and total columns (TotC) at Izaña (right) (blue: FTIR, red: MLR model). Middle panels: same but with the seasonal signal removed. Bottom panels: QBO and AO signals obtained from the MLR model at Jungfraujoch (left), SOLAR signal at Wollongong (middle), and QBO signal at Izaña (right). 
also the only station where the ENSO proxy was found to make a significant, but small, contribution to the variability (Fig. 4). We illustrate the QBO effect at Izaña in Fig. 9 for total columns.

\subsubsection{Middle stratospheric (MidS) columns}

The situation for the middle stratosphere is very similar to that of the lower stratosphere: all trends are found nonsignificant except at Wollongong where it is positive. It is in this $23-32 \mathrm{~km}$ layer for subtropical stations that the solar cycle shows the most important contribution (Fig. 4). This is not what has been reported in Randel and Wu (2007) and Tourpali et al. (2007), where the ozone response to the solar cycle was maximum in the tropical lower and upper stratosphere, and minimum in the middle stratosphere. At Wollongong, the middle stratospheric ozone response is about $6 \%$ between solar minimum and solar maximum (see Fig. 9) while values of $1 \%$ have been reported (Sioris et al., 2014) at about $25 \mathrm{~km}$. However, the recent work of Chiodo et al. (2014) shows that the apparent solar cycle signal in the tropical lower stratosphere for the period 1960-2004 is due to the two volcanic eruptions of El Chichón in 1982 and Mt. Pinatubo in 1991, and the authors find robust solar cycle signals only in the middle and upper stratosphere. In the upper stratospheric layer at Wollongong, the response to the solar cycle is indeed also significant and is about $2.5 \%$ between solar minimum and solar maximum which is in agreement with previous studies (WMO, 2010). At Izaña, the solar contribution is found negative in the $23-32 \mathrm{~km}$ layer, which seems doubtful. Again, this concerned one of the shortest time series of the study (1999-2012) and could be corrected with future measurements.

\subsubsection{Upper stratospheric (UppS) columns}

The trends in the upper stratospheric layer are all positive in these latitudes but significant only at Lauder $(+2.8 \pm$ $2.4 \%$ decade $\left.^{-1}\right)$. Our trend at Jungfraujoch station $(+0.9 \pm$ $1.0 \%$ decade $\left.^{-1}\right)$ corresponds well to the observed trend $\left(+1.5 \%\right.$ decade $\left.^{-1}\right)$ at OHP in Nair et al. (2013) in the 31$39 \mathrm{~km}$ range, although it is found significant in this latter study. The MLR model explains $93 \%$ of the variability at Jungfraujoch $\left(R^{2}=0.93\right)$, namely, $77 \%$ of the variability comes from the seasonality and the remaining $16 \%$ from the proxies, mainly the ELU and QBO (see Fig. 4). At Lauder, the trend in the $30-40 \mathrm{~km}$ range from lidar measurements is also found significantly positive for the period 2000-2012 with trend values $\left(+2-3 \%\right.$ decade $\left.^{-1}\right)$ similar to FTIR (W. Steinbrecht, personal communication, 2013). If we remove the solar cycle signal in the MLR for the short time series of Lauder, the trend becomes smaller and nonsignificant $\left(+1.7 \pm 2.4 \%\right.$ decade $\left.^{-1}\right)$. More years of data will improve the confidence in the solar cycle signal in the short time series.

\subsubsection{Total columns}

The total column trends are non-significant at the mid-latitude stations $\left(-0.4 \pm 1.2 \% \mathrm{decade}^{-1}\right.$ or $-1.4 \pm$

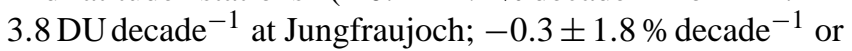
$-1.1 \pm 5.9 \mathrm{DU}^{-1 e c a d e^{-1}}$ at Lauder), non-significant at Izaña $\left(+0.5 \pm 1.2 \%\right.$ decade $^{-1}$ or $\left.+1.4 \pm 3.6 \mathrm{DU}_{\text {decade }}-1\right)$, and significantly positive at Wollongong $\left(+1.9 \pm 1.1 \% \mathrm{decade}^{-1}\right.$ or $+5.8 \pm 3.5 \mathrm{DUdecade}^{-1}$ ). The total column trend at Jungfraujoch is in agreement within error bars with the result of Nair et al. (2013) at OHP when they use the PWLT method $\left(+5.5 \pm 3.3 \mathrm{DUdecade}^{-1}\right)$, but again the trend at OHP is found significantly positive. When the EESC proxy is used in their study a trend of $+4.2 \pm 0.8 \mathrm{DUdecade}^{-1}$ is found. The same behavior is seen more globally in a recent study using merged satellite data from 1979 to 2012 (Chehade et al., 2014): for the latitude of Jungfraujoch, the trends are about +3-4 DU decade ${ }^{-1}$ for the 1997-2012 period and non-significant if the PWLT method is used, while significant when the EESC proxy is used, which decreases the uncertainty on the trends. It seems that at Jungfraujoch, our time series is still too short to observe this positive trend. At the latitude of Izaña, the merged satellite data set shows a +3-4 DU decade ${ }^{-1}$ for the 1997-2012 period, with the more recent SBUV/SBUV-2 MOD v8.6, non-significant using the PWLT (in agreement with our study) and significant using the EESC proxy. Since our time series start at best in 1995, the EESC proxy is not really "separable" from a linear trend study at our mid-latitude and subtropical stations. When more years of data are available, the same sensitivity study (PWLT vs. EESC) could be tested at least for polar stations where the turnaround point is expected around 2000.

It is also interesting to note that, using the PWLT method, at the latitude of Wollongong, Chehade et al. (2014) found a positive significant trend of about $+3 \mathrm{DUdecade}{ }^{-1}$, while at the latitude of Lauder the trend is decreased to about $+1 \mathrm{DU}_{\text {decade }}{ }^{-1}$ (non-significant) in good agreement with what FTIR observed. When they use the EESC proxy, the trend is increasing with latitude so that at the Lauder latitude it reaches about 4-5 DU decade ${ }^{-1}$.

Our non-significant trends at Jungfraujoch, Izaña and Lauder, and positive trend at Wollongong are also in agreement with the recent study of Coldewey-Egbers et al. (2014), which provides trends using a similar period (1995-2013) of merged satellite data sets. For Wollongong, since the total column positive trend is due to the ozone trends in the lower and middle stratosphere, it cannot be attributed unambiguously to the EESCs decline.

\section{Conclusions}

We have exploited the time series of ozone total and partial columns (Trop, LowS, MidS, UppS) at eight NDACC FTIR stations (Ny-Ålesund, $79^{\circ} \mathrm{N}$; Thule, $77^{\circ} \mathrm{N}$; Kiruna, $68^{\circ} \mathrm{N}$; 
Harestua, $60^{\circ} \mathrm{N}$; Jungfraujoch, $47^{\circ} \mathrm{N}$; Izaña, $28^{\circ} \mathrm{N}$; Wollongong, $34^{\circ} \mathrm{S}$; Lauder, $45^{\circ} \mathrm{S}$ ) to derive vertically resolved trends, using a MLR model including the main proxies wellknown for impacting the ozone variability.

After the seasonal variation, the TP proxy is the dominant driver of ozone variability at all stations, mainly for the troposphere, lower stratosphere and total columns, while the EL proxy is an important contributor to the middle and upper stratosphere, as well as to the total column variabilities. At the highest latitude stations $\left(68-79^{\circ} \mathrm{N}\right)$, the EPF proxy contributes substantially to the middle stratospheric and total column variabilities. The VPSC proxy for polar ozone loss contributes to the lower stratosphere and total column variabilities at the Arctic stations but also at Jungfraujoch, while is it non-significant at the southern hemispheric station Lauder. At the mid-latitude and subtropical stations, the QBO proxy is a substantial contributor to ozone variability, especially at the lowest latitude station, Izaña. The AO/AAO and ENSO proxies are significant only at Jungfraujoch and Izaña, respectively. At Wollongong, the $2.5 \%$ ozone response to solar cycle in the upper layer is in agreement with previous studies, but the response in the middle stratosphere $(\sim 6 \%)$ is much larger than previously reported $(\sim 1 \%)$. The 11year solar cycle effect is still subject of debate (WMO, 2010; Chiodo et al., 2014), so that an additional decade of measurements would help in fixing its real impact on ozone. This is particularly true for our shortest time series of Lauder, Izaña and Thule.

The trends at the high latitude stations are negative in the troposphere, except at Kiruna where it is non-significant. Except at Thule, the high latitude stations show significant negative trends in the lower stratosphere. The situation is mixed in the middle stratosphere where the trend is significantly negative at Ny-Ålesund, non-significant at Thule and Kiruna, and significantly positive at Harestua. The trends of the three high latitude stations with a similar time period are all positive in the upper stratosphere, but this increase is taking place during the 1995-2003 period while the EESCs were still increasing until about 2000 in the polar region (WMO, 2010). However all four stations give non-significant trends in the upper stratosphere for the October 1999-2012 period, which could be the onset of the upper stratospheric ozone recovery at high latitude. The total column trends are non-significant at all high latitude stations, except at Ny-Ålesund where it is negative. This is in agreement (except at Ny-Ålesund) with model predictions that the Arctic March ozone recovery to 1980 levels will occur around 2026 (WMO, 2010). However, the high year-to-year total column variability at these latitudes, driven mainly by lower stratospheric variability due to the polar temperature variations, does not allow yet to draw conclusions from the current trends for Arctic total ozone in the coming few years.
The trends for mid-latitude and subtropical stations are all non-significant, except at Lauder in the troposphere and upper stratosphere and at Wollongong for the total columns and the lower and middle stratospheric columns. Some signs of the onset of ozone mid-latitude recovery are observed only in the Southern Hemisphere, while a few more years seem to be needed to observe it at the northern stations.

To conclude, among the numerous available satellite and ground-based data sets measuring vertical distributions of ozone that are useful for ozone trend evaluations (Hassler et al., 2014), the NDACC ground-based FTIR measurements have their particular assets. Indeed, several stations, well distributed around the globe, are now reaching almost 20 years of measurements and will continue measuring ozone in the future: to the eight stations of this work could be added, after homogenization of the retrieval analysis and/or few more years of data, Eureka $\left(80^{\circ} \mathrm{N}\right)$, Rikubetsu $\left(44^{\circ} \mathrm{N}\right)$, Bremen $\left(53^{\circ} \mathrm{N}\right)$, Mauna Loa $\left(20^{\circ} \mathrm{N}\right)$, and Arrival Heights $\left(78^{\circ} \mathrm{S}\right)$. This provides long time series of ozone that are reliable over time, provided that the ILS is properly taken into account. This is also the only data set, with Umkehr measurements, that provides simultaneously total columns, tropospheric columns and three stratospheric columns that reach $40-45 \mathrm{~km}$. This data set is suitable for an alternative determination of ozone vertical changes, as demonstrated in this study, but also for validation of the satellite-merged data sets and detection of possible drifts.

Acknowledgements. The National Center for Atmospheric Research is supported by the National Science Foundation. The observation program at Thule, Greenland, is supported under contract by the National Aeronautics and Space Administration and the site is also supported by the NSF Office of Polar Programs. We wish to thank the Danish Meteorological Institute for support at Thule. We would like to thank U. Raffalski and P. Völger for technical support at IRF Kiruna. The University of Liège team acknowledges the support of the F.R.S. - FNRS, the Fédération Wallonie-Bruxelles, the International Foundation High Altitude Research Stations Jungfraujoch and Gornergrat (HFSJG, Bern) and Meteoswiss. The NIWA Lauder MIR-FTIR project is core-funded through New Zealand's Ministry of Business, Innovation and Employment. We are grateful to the many colleagues having contributed to FTIR data acquisition at the various sites. We wish to thank S. Godin-Beekmann and M. Pastel (LATMOS) for useful discussions on equivalent latitude proxy, and R. Kivi (KMI) for discussion on ozonesonde trends in the Arctic. This study has been supported by the EU FP7 project NORS, the ESA PRODEX project $\mathrm{A} 3 \mathrm{C}$, as well as the AGACC-II project within the Science for a Sustainable Development research program funded by the Belgian Science Policy Office.

Edited by: M. Dameris 


\section{References}

Appenzeller, C., Weiss, A. K., and Staehelin, J.: North Atlantic Oscillation modulates total ozone winter trends, Geophys. Res. Lett., 27, 1131-1134, 2000.

Barret, B., De Mazière, M., and Demoulin, P.: Retrieval and characterization of ozone profiles from solar infrared spectra at the Jungfraujoch, J. Geophys. Res., 107, 4788, doi:10.1029/2001JD001298, 2002.

Bodeker, G. E., Hassler, B., Young, P. J., and Portmann, R. W.: A vertically resolved, global, gap-free ozone database for assessing or constraining global climate model simulations, Earth Syst. Sci. Data, 5, 31-43, doi:10.5194/essd-5-31-2013, 2013.

Brasseur, G. and Solomon, S: Aeronomy of the Middle Atmosphere, 441 pp., D. Reidel Publishing Company, Dordrecht, Holland, 1984.

Brunner, D., Staehelin, J., Maeder, J. A., Wohltmann, I., and Bodeker, G. E.: Variability and trends in total and vertically resolved stratospheric ozone based on the CATO ozone data set, Atmos. Chem. Phys., 6, 4985-5008, doi:10.5194/acp-6-49852006, 2006.

Chandra, S., Ziemke, J. R., and Stewart, R. W.: An 11-year solar cycle in tropospheric ozone from TOMS measurements, Geophys. Res. Lett., 26, 185-188, 1999.

Chehade, W., Weber, M., and Burrows, J. P.: Total ozone trends and variability during 1979-2012 from merged data sets of various satellites, Atmos. Chem. Phys., 14, 7059-7074, doi:10.5194/acp14-7059-2014, 2014.

Chiodo, G., Marsh, D. R., Garcia-Herrera, R., Calvo, N., and García, J. A.: On the detection of the solar signal in the tropical stratosphere, Atmos. Chem. Phys., 14, 5251-5269, doi:10.5194/acp-14-5251-2014, 2014.

Cochrane, D. and Orcutt, G. H.: Application of least squares regression to relationships containing auto-correlated error terms, J. Am. Stat. Assoc., 44, 32-61, 1949.

Coldewey-Egbers, M., Loyola, D. G., Braesicke, P., Dameris, M., van Roozendael, M., Lerot, C., and Zimmer, W.: A new health check of the ozone layer at global and regional scales, Geophys. Res. Lett., 41, 4363-4372, doi:10.1002/2014GL060212, 2014.

Dee, D. P., Uppala, S. M., Simmons, A. J., Berrisford, P., Poli, P., Kobayashi, S., Andrae, U., Balmaseda, M. A., Balsamo, G., Bauer, P., Bechtold, P., Beljaars, A. C. M., van de Berg, L., Bidlot, J., Bormann, N., Delsol, C., Dragani, R., Fuentes, M., Geer, A. J., Haimberger, L., Healy, S. B., Hersbach, H., Hólm, E. V., Isaksen, L., Kållberg, P., Köhler, M., Matricardi, M., McNally, A. P., Monge-Sanz, B. M., Morcrette, J.-J., Park, B.K., Peubey, C., de Rosnay, P., Tavolato, C., Thépaut, J.-N., and Vitart, F.: The ERA-Interim reanalysis: configuration and performance of the data assimilation system, Q. J. Roy. Meteor. Soc., 137, 553-597, doi:10.1002/qj.828, 2011.

Frossard, L., Rieder, H. E., Ribatet, M., Staehelin, J., Maeder, J. A., Di Rocco, S., Davison, A. C., and Peter, T.: On the relationship between total ozone and atmospheric dynamics and chemistry at mid-latitudes - Part 1: Statistical models and spatial fingerprints of atmospheric dynamics and chemistry, Atmos. Chem. Phys., 13, 147-164, doi:10.5194/acp-13-147-2013, 2013.

García, O. E., Schneider, M., Redondas, A., González, Y., Hase, F., Blumenstock, T., and Sepúlveda, E.: Investigating the longterm evolution of subtropical ozone profiles applying ground- based FTIR spectrometry, Atmos. Meas. Tech., 5, 2917-2931, doi:10.5194/amt-5-2917-2012, 2012.

Garcia, R. R., Marsh, D. R., Kinnison, D. E., Boville, B. A., and Sassi, F.: Simulation of secular trends in the middle atmosphere, 1950-2003, J. Geophys. Res., 112, D09301, doi:10.1029/2006JD007485, 2007.

Hase, F., Blumenstock, T., and Paton-Walsh, C.:Analysis of the instrumental line shape of high-resolution Fourier transform IR spectrometers with gas cell measurements and new retrieval software, Appl. Optics, 38, 3417-3422, 1999.

Hase, F.: Inversion von Spurengasprofilen aus hochaufgelösten bodengebundenen FTIR-Messungen in Absorption, Dissertation, Wissenschaftliche Berichte Forschungszentrum Karlsruhe, FZKA 6512; ISSN 0947-8620, Forschungszentrum Karlsruhe, Karlsruhe, Germany, 2000.

Hase, F., Hannigan, J. W., Coffey, M. T., Goldman, A., Höpfner, M., Jones, N. B., Rinsland, C. P., and Wood, S. W.: Intercomparison of retrieval codes used for the analysis of high-resolution, ground-based FTIR measurements, J. Quant. Spectrosc. Ra., 87, 25-52, 2004.

Hassler, B., Petropavlovskikh, I., Staehelin, J., August, T., Bhartia, P. K., Clerbaux, C., Degenstein, D., Mazière, M. De, Dinelli, B. M., Dudhia, A., Dufour, G., Frith, S. M., Froidevaux, L., Godin-Beekmann, S., Granville, J., Harris, N. R. P., Hoppel, K., Hubert, D., Kasai, Y., Kurylo, M. J., Kyrölä, E., Lambert, J.-C., Levelt, P. F., McElroy, C. T., McPeters, R. D., Munro, R., Nakajima, H., Parrish, A., Raspollini, P., Remsberg, E. E., Rosenlof, K. H., Rozanov, A., Sano, T., Sasano, Y., Shiotani, M., Smit, H. G. J., Stiller, G., Tamminen, J., Tarasick, D. W., Urban, J., van $\operatorname{der}$ A, R. J., Veefkind, J. P., Vigouroux, C., von Clarmann, T., von Savigny, C., Walker, K. A., Weber, M., Wild, J., and Zawodny, J. M.: Past changes in the vertical distribution of ozone - Part 1: Measurement techniques, uncertainties and availability, Atmos. Meas. Tech., 7, 1395-1427, doi:10.5194/amt-7-1395-2014, 2014.

Kyrölä, E., Laine, M., Sofieva, V., Tamminen, J., Päivärinta, S.-M., Tukiainen, S., Zawodny, J., and Thomason, L.: Combined SAGE II-GOMOS ozone profile data set for 1984-2011 and trend analysis of the vertical distribution of ozone, Atmos. Chem. Phys., 13, 10645-10658, doi:10.5194/acp-13-10645-2013, 2013.

Logan, J. A., Staehelin, J., Megretskaia, I. A., Cammas, J.P., Thouret, V., Claude, H., De Backer, H., Steinbacher, M., Scheel, H.-E., Stübi, R., Fröhlich, M., and Derwent, R.: Changes in ozone over Europe: Analysis of ozone measurements from sondes, regular aircraft (MOZAIC) and alpine surface sites, J. Geophys. Res., 117, D09301, doi:10.1029/2011JD016952, 2012.

Mikuteit, S.: Trendbestimmung stratosphärischer Spurengase mit Hilfe bodengebundener FTIR-Messungen, Dissertation, Forschungszentrum Karlsruhe, FZK Report No. 7385, Germany, 2008.

Nair, P. J., Godin-Beekmann, S., Kuttippurath, J., Ancellet, G., Goutail, F., Pazmiño, A., Froidevaux, L., Zawodny, J. M., Evans, R. D., Wang, H. J., Anderson, J., and Pastel, M.: Ozone trends derived from the total column and vertical profiles at a northern mid-latitude station, Atmos. Chem. Phys., 13, 1037310384, doi:10.5194/acp-13-10373-2013, 2013.

Newchurch, M. J., Yang, E.-S., Cunnold, D. M.,Reinsel, G. C., Zawodny, J. M., and Russell III, J. M.: Evidence for slowdown in 
stratospheric ozone loss: First stage of ozone recovery, J. Geophys. Res., 108, 4507, doi:10.1029/2003JD003471, 2003.

Oltmans, S. J., Lefohn, A. S., Shadwick, D., Harris, J. M., Scheel, H. E., Galbally, I., Tarasick, D. W., Johnson, B. J., Brunke, E.-G., Claude, H., Zeng, G., Nichol, S., Schmidlin, F., Davies, J., Cuevas, E., Redondas, A., Naoe, H., Nakano, T., Kawasato, T.: Recent tropospheric ozone changes - a pattern dominated by slow or no growth, Atmos. Environ., 67, 331-351, 2013.

Pougatchev, N. S., Connor, B. J., and Rinsland, C. P.:Infrared measurements of the ozone vertical distribution above Kitt Peak, J. Geophys. Res., 100, 16689-16697, 1995.

Randel, W. J., and Wu, F.: A stratospheric ozone profile data set for 1979-2005: Variability, trends, and comparisons with column ozone data, J. Geophys. Res., 112, D06313, doi:10.1029/2006JD007339, 2007.

Randel, W. J., Garcia, R. R., Calvo, N., and Marsh, D.: ENSO influence on zonal mean temperature and ozone in the tropical lower stratosphere, Geophys. Res. Lett., 36, L15822, doi:10.1029/2009GL039343, 2009.

Rodgers, C. D.: Inverse methods for atmospheric sounding: Theory and Practice, Series on Atmospheric, Oceanic and Planetary Physics - Vol. 2, World Scientific Publishing Co., Singapore, 2000.

Rothman, L. S., Gordon, I. E., Barbe, A., Benner, D. C., Bernath, P. F., Birk, M., Boudon, V., Brown, L. R., Campargue, A., Champion, J.-P., Chance, K., Coudert, L. H., Danaj, V., Devi, V. M., Fally, S., Flaud, J.-M., Gamache, R. R., Goldmanm, A., Jacquemart, D., Kleiner, I., Lacome, N., Lafferty, W. J., Mandin, J.-Y., Massie, S. T., Mikhailenko, S. N., Miller, C. E., Moazzen-Ahmadi, N., Naumenko, O. V., Nikitin, A. V., Orphal, J., Perevalov, V. I., Perrin, A., PredoiCross, A., Rinsland, C. P., Rotger, M., Šimečková, M., Smith, M. A. H., Sung, K., Tashkun, S. A., Tennyson, J., Toth, R. A., Vandaele, A. C., and Vander Auwera, J.: The Hitran 2008 molecular spectroscopic database, J. Quant. Spectrosc. Ra., 110, 533-572, 2009.

Scherrer, B.: Biostatistique, Gaëtan Morin, Chicoutimi, 1984.

Schneider, M., Hase, F., and Blumenstock, T.: Ground-based remote sensing of $\mathrm{HDO} / \mathrm{H} 2 \mathrm{O}$ ratio profiles: introduction and validation of an innovative retrieval approach, Atmos. Chem. Phys., 6, 4705-4722, doi:10.5194/acp-6-4705-2006, 2006.
Sioris, C. E., McLinden, C. A., Fioletov, V. E., Adams, C., Zawodny, J. M., Bourassa, A. E., Roth, C. Z., and Degenstein, D. A.: Trend and variability in ozone in the tropical lower stratosphere over 2.5 solar cycles observed by SAGE II and OSIRIS, Atmos. Chem. Phys., 14, 3479-3496, doi:10.5194/acp14-3479-2014, 2014.

Sussmann, R., Borsdorff, T., Rettinger, M., Camy-Peyret, C., Demoulin, P., Duchatelet, P., Mahieu, E., and Servais, C.: Technical Note: Harmonized retrieval of column-integrated atmospheric water vapor from the FTIR network - first examples for longterm records and station trends, Atmos. Chem. Phys., 9, 89878999, doi:10.5194/acp-9-8987-2009, 2009.

Tikhonov, A.: On the solution of incorrectly stated problems and a method of regularization, Dokl. Acad. Nauk SSSR, 151, 501504, 1963.

Tourpali, K., Zerefos, C. S., Balis, D. S., and Bais, A. F.: The 11-year solar cycle in stratospheric ozone: comparison between Umkehr and SBUVv8 and effects on surface erythemal irradiance, J. Geophys. Res., 112, D12306, doi:10.1029/2006JD007760, 2007.

Vigouroux, C., De Mazière, M., Demoulin, P., Servais, C., Hase, F., Blumenstock, T., Kramer, I., Schneider, M., Mellqvist, J., Strandberg, A., Velazco, V., Notholt, J., Sussmann, R., Stremme, W., Rockmann, A., Gardiner, T., Coleman, M., and Woods, P.: Evaluation of tropospheric and stratospheric ozone trends over Western Europe from ground-based FTIR network observations, Atmos. Chem. Phys., 8, 6865-6886, 2008, http://www.atmos-chem-phys.net/8/6865/2008/.

Weber, M., Dikty, S., Burrows, J. P., Garny, H., Dameris, M., Kubin, A., Abalichin, J., and Langematz, U.: The Brewer-Dobson circulation and total ozone from seasonal to decadal time scales, Atmos. Chem. Phys., 11, 11221-11235, doi:10.5194/acp-1111221-2011, 2011.

Wohltmann, I., Rex, M., Brunner, D., and Mäder: Integrated equivalent latitude as a proxy for dynamical changes in ozone column, Geophys. Res. Lett., 32, L09811, doi:10.1029/2005GL022497, 2005.

World Meteorological Organization: Atmospheric Ozone: 1985, Global Ozone Research and Monitoring Project - Report No. 16, Geneva, 1998.

World Meteorological Organization: Scientific Assessment of Ozone Depletion: 1998, Global Ozone Research and Monitoring Project - Report No. 44, Geneva, 1998.

World Meteorological Organization: Scientific Assessment of Ozone Depletion: 2010, Global Ozone Research and Monitoring Project - Report No. 52, Geneva, 2011. 